\title{
COMMENTS
}

\section{GUIDELINES FOR EXTENDING IMPLIED \\ WARRANTIES TO SERVICE MARKETS}

\section{TABLE OF CONTENTS}

I. A Basic Model of Information-Impacted Markets 367

A. Elements in Consumer Product Assessment ....... 367

B. Conditions and Motivations of Service Production ... 369

C. Categorizing Information-Impacted Markets ....... 371

D. Obstacles to Voluntary Insurance ............. 374

E. Providing Information as a Competitive Strategy . . . 377

F. Repeat Buying as a Consumer Strategy .......... 379

II. Application of the Model: Choosing the Appropriate Legal Rule for Particular Service Markets -A Decisional Framework for the Courts ..... 382

A. The Impact of Implied Guarantees ........... 382

1. Combating Deterioration and Opportunism 383

2. Other Key Features of Implied Guarantees 386

B. Preliminary Inquiries and Guidelines for Adjudication 389

III. Judicial Decisionmaking Concerning Appropriate IMPLIED GuARANTEES $\ldots \ldots \ldots \ldots \ldots \ldots \ldots \ldots \ldots . \ldots \ldots$

A. The Current State of the Law ............. 393

B. Gagne-Unresolved Contradictions in an Important Precedent ........................... 397

C. Broyles-Uncertainty as a Faulty Boundary on Implied Warranties ........................ 402

D. Newmark—Long Step Toward Useful Analysis ... 408 IV. The Decisional Framework Revisited: Its Limits 413

Important legislative and judicial measures taken in recent years to extend greater warranty protection to consumers generally have not reached into markets for services. ${ }^{1}$ Agencies that process consumer complaints frequently find that certain service markets, particularly auto repairs and home improve-

${ }^{1}$ For a discussion of the current state of the law, see notes 79-98 infra \& accompanying text. 
ments, ${ }^{2}$ account for a disproportionate share of customer dissatisfaction. Nevertheless, aggrieved service consumers usually cannot avail themselves of the theories of recovery commonly available to consumers of goods: implied warranty and strict liability in tort. The only "implied guarantee"-that is, an externally imposed promise from seller to buyer-widely given to dissatisfied consumers of services is that recovery of damages will follow a showing that the service provider negligently performed his tasks. ${ }^{3}$ The complexity and importance of many services suggest a need for greater consumer protection, but the courts repeatedly have chosen to forego opportunities to depart from the traditional negligence rule for services. ${ }^{4}$

In order to assess the logic of applying different legal standards of implied guarantees to sellers of goods and sellers of services, this Comment will develop a description or model of what economists refer to as "information-impacted markets." These are markets in which two parties bargain about a proposed transaction, but with one party possessing important information that cannot be transferred costlessly to the other. ${ }^{5}$ The model of this type of market, based on a series of simplifying assumptions concerning the crucial elements that influence consumers' choicemaking and businesses' production and marketing behavior, will incorporate key features that distinguish service markets from goods markets. So developed, the model will be used to predict outcomes, both with and without the imposition of legally implied guarantees, in various types of information-impacted service markets. Employing these predictions of the likely market impact of alternative legal rules along with important noneconomic considerations, the Comment

${ }^{2}$ See S. Margolius, The Innocent Consumer vs. The Exploiters 155-64, 176 (1976). See generally Hearings on S.R. 233 Before the Subcomm. on Antitrust and Monopoly of the Senate Comm. on the Judiciary, 90th Cong., 2d Sess., pt. 1 (1969); Hearings on S.R. 40 Before the Subcomm. on Antitrust and Monopoly of the Senate Comm. on the Judiciary, 91st Cong., 1st Sess., pt. 2 (1969); Hearings on S.R. 40 Before the Subcomm. on Antitrust and Monopoly of the Senate Comm. on the Judiciary, 91st Cong., lst Sess., pt. 3 (1970); Hearings on S.R. 334 Before the Subcomm. on Antitrust and Monopoly of the Senate Comm. on the Judiciary, 91st Cong., 2d Sess., pt. 4 (1970); Hearings on S.R. 40 Before the Subcomm. on Antitrust and Monopoly of the Senate Comm. on the Judiciary, 91st Cong., 2d Sess., pts. 5 \& 6 (1971) (appendices).

${ }^{3}$ The principal comparison in this regard is between implied guarantees of the negligence type and those reflecting an implied warranty. Compare notes 56-57 infra \& accompanying text with UNIForm CoMmercial CoDE $\$$ 2-314, -315.

${ }^{4}$ See notes 79-98 infra \& accompanying text.

${ }^{5}$ O. Williamson, Markets and Hierarchies: ANalysis and Antitrust ImpliCations 31 (1975). See generally Spence, An Economist's View of Information, 9 AnN. Rev. INFO. SCI. \& TECH. 57-78 (1974). 
then will evaluate the current discrepancy between the standards applied to providers of goods and providers of services, consider the extent to which even the best chosen legal guarantee can protect consumers in information-impacted situations, and recommend a process by which courts can decide future cases requiring them to choose an appropriate rule for a particular service market. Finally, the proposed considerations will be related to the facts and reasoning in three prominent cases involving the sale of services-Gagne v. Bertran, ${ }^{6}$ Broyles $v$. Brown Engineering Co. ${ }^{7}$ and Newmark v. Gimbel's, Inc. ${ }^{8}$

\section{A Basic Model of Information-Impacted Markets}

\section{A. Elements in Consumer Product Assessment}

Hypotheses concerning four major input sources into consumers' comparative judgments of product quality provide a foundation for building a model of information-impacted markets. ${ }^{9}$ The most obvious element in a consumer's assessment of product quality is information gleaned by "inspection" of the product itself. If the product is not particularly complicated and many different brands are available for easy and inexpensive examination, then this component may be quite important in the consumer's overall quality judgment. Students of consumer behavior, however, have found that assessments of quality often hinge not on detailed inspection, but on readily observable product features, which this Comment will call "cues," even if these features actually have only a very loose relationship to

643 Cal. 2d 481, 275 P.2d 15 (1954).

7275 Ala. 35, 151 So. 2d 767 (1963) (per curiam).

${ }^{8} 54$ N.J. 585, 258 A.2d 697 (1969).

9 Because detailed individual notes would not conveniently or accurately reflect the real background for the model presented here, the seminal works of economic research inspiring it should be identified at the outset. The crucial constituent elements are the concepts of comparative institutional modes and transaction costs, see O. Williamson, supra note 5, the economic and legal analysis of liability rules, see, e.g., G. Calabresi, The Costs of Accidents (1970), the economic role of information, see, e.g., Stigler, The Economics of Information, $69 \mathrm{~J}$. PoL. EcoN. 213 (1961), the relationship between quality and information, see Akerlof, The Market for 'Lemons': Qualitative Uncertainty and the Market Mechanism, 84 Q.J. EcoN. 488 (1970), the consumer as information seeker, see, e.g., Nelson, Information and Consumer Behavior, $78 \mathrm{~J}$. PoL. Econ. 311 (1970), and the economics of insurance, see, e.g., K. ARRow, Insurance, Risk and Resource Allocation in Essays IN THE THeORY of RIsk Bearing 134 (1971). In addition, an effort has been made to draw on the vast quantity of empirical research into consumer behavior done by market researchers, a source outside the normal stream of economic literature. Citations are given where appropriate. The reader who is familiar with positions taken in much of the economics literature mentioned above will want to notice the extent to which they and the conclusions presented here differ, especially with respect to the ability of the competitive market to alleviate information related problems. 
true quality. ${ }^{10}$ For example, early studies revealed that shoppers' estimates of the durability of nylons varied with the scent of the stockings ${ }^{11}$ and that consumers resisted buying mixers that ran too quietly because noise was considered a crucial indicator of power. ${ }^{12}$ Market researchers currently believe that the most important cues are brand name and price. ${ }^{13}$ Consumers have also been found to base their product assessments on "experience," both their own and that of friends with whom they consult. ${ }^{14}$ Past experiences may be a particularly valuable source of information if the product is purchased frequently so that many experiences can accumulate, or if the consumer has friends with particular expertise who can interpret complicated experiences meaningfully. Finally, consumers invariably have some general "hunch" about the quality to be expected from any given product, regardless of the particular brand purchased or the lack of any brand-specific knowledge. This general expectation may well be crucial in the initial decision to buy the product, a judgment often made prior to and in isolation from the final choice of a specific supplier's merchandise.

To a significant extent, the anticipated effect of information impactedness on any particular market depends on the relative importance of these four elements-inspection, cues, experience, and hunch-in the quality judgments actually made by most consumers. A prominent feature of nearly all service markets, indeed the key to labeling them "information impacted," is that the consumer cannot conduct prepurchase inspections of services he is considering buying; the service does not "exist" until it is performed for him. He can inspect the service provider's facilities, but much of what he observes are cues rather than direct quality-related characteristics. ${ }^{15}$ The import of the other three elements varies markedly depending on the service being purchased. Cues, for example, vary in importance

${ }^{10}$ See Cox, The Sorting Rule Model of the Consumer Product Evaluation Process, in Risk Taking and Information Handling in Consumer Behavior 324 (D. Cox ed. 1967).

${ }^{11}$ See Laird, How the Consumer Estimates Quality by Subconscious Sensory Impressions, 16 J. Applied Psych. 241 (1932).

${ }^{12}$ See Froman, You Get What You Want, in Readings in Marketing 231 (J. H. Westing ed. 1953).

${ }^{13}$ See, e.g., Monroe, Buyer's Subjective Perceptions of Price, $10 \mathrm{~J}$. Marketing Research 70 (1973).

${ }^{14}$ See, e.g., Arndt, Word of Mouth Advertising and Informal Communication, in RISK Taking and Information Handling in Consumer Behavior 188 (D. Cox ed. 1967).

${ }^{15}$ Even supposedly noncommercialized premises may stimulate substantial cue responses, such as, for example, the decor of an attorney's office or the locale and "status" of the building in which it is located. Other premises, including some beauty parlors, are intentionally designed to maximize positive cue responses. 
because some service providers maintain premises that are more cue-laden than others, some services operate under professional codes that attempt to restrict sharply cue transmission, especially via advertising, ${ }^{16}$ and some service markets are dominated by very small service providers who cannot utilize the type of broadly based media campaigns that can stress and exaggerate cue responses. Similarly, experience can be an important factor in cases, such as cleaning and moving services, in which consumers can meaningfully and accurately judge the quality of the service received after its performance. In many important service categories, however, even such after-the-fact assessments are inaccurate. Thus, when a consumer purchases repair or restorative services on a complex durable good, such as his car, or on his own body, he is able to determine subsequently how his car runs or how he feels, but that may give him little insight into the actual quality of the work done. ${ }^{17}$ With scant understanding of the complexities of his original problem, he is hardpressed to evaluate whether the labor performed was actually necessary or if problems that surface later could have been avoided had the original repairs been more skillfully executed. Reliance on one's own and others' past experiences is more difficult if the service is infrequently purchased, such as home improvements, or if the sellers rapidly appear and disappear in the market, such as various seasonal services. If inspection, cues, and experience are all inoperative in the market, an uninformed and unfocused hunch is all the basis for choice left the consumer, and its importance grows accordingly.

\section{B. Conditions and Motivations of Service Production}

Several key features of service markets from the viewpoint of producers are also incorporated into this model. First, most services are produced on demand after a deal has been struck with an individual customer, rather than being massproduced prior to a firm agreement of sale with the ultimate consumer. Second, many complicated services, such as medical care and investment advice, are characterized by a substantial amount of production uncertainty in the sense that even the best efforts of the most skilled practitioner may not have a high probability of producing the result sought by the purchaser. ${ }^{18}$ (1970).

${ }^{16}$ See, e.g., ABA Code of Professional Responsibility, Canon 2, EC 2-9 to -11

${ }^{17}$ See, e.g., Darby \& Karni, Free Competition and the Optimal Amount of Fraud, $16 \mathrm{~J}$. LAW \& ECON. 67, 69 (1973).

${ }^{18}$ Of course, there will be tremendous variation in the degree of uncertainty pre- 
It is reasonable to assume, however, that the service provider has some measure of control over this uncertainty in that he has a range of techniques available to him in performing the service, some of which involve more time and care than others and therefore have a somewhat greater probability of achieving satisfactory results. For example, law firms cannot be sure that taking certain steps will lead to a favorable outcome in complex litigation, but they nonetheless recognize that the probability of a favorable verdict varies with the attorneys assigned to the case and the size of their outside workloads, to identify just two elements. ${ }^{19}$ Third, although the Comment later examines the question of possible differences between services based on the extent to which socialization processes, professional ethical codes, and similar forces may engender a substantially different type of motivation, ${ }^{20}$ the model assumes initially that service providers are basically profit oriented. Finally, given that quality partly measures the probability of a satisfactory result but that cost-free quality changes are no longer possible, ${ }^{21}$ the framework accepts the proposition that any attempts to improve quality must involve necessarily a more careful and hence expensive process for the service provider.

Insofar as quality improvements increase costs and quality reductions lower costs, given the assumptions made to this point, predictions of market outcomes depend essentially on the revenue consequences of different levels of output quality to service providers. Since prepurchase product inspections are not possible, consumers appear at a service provider's door because of the cues they have observed, their own and their friends' experiences with the service provider's past quality, and their hunches about the product. Current improvements

vailing in the production of different services and even in the completion of different specific activities within one service. Thus, open heart surgery presumably has a more dispersed (uncertain) distribution of outcomes for any given level of effort than does setting a broken arm.

${ }_{19}$ The choice of techniques, as this example is intended to indicate, should often be assessed from a management perspective, as well as that of the individual service provider. The management viewpoint broadens substantially the choices available and is consistent with the focus on choice, as exercised by the one who can profit from it. Thus, although in some situations it may appear as though the individuals involved simply "do their job" with no conscious selection or variation of methods, management does exercise a choice of techniques in the work assignment sense, as shown in the law firm example, and, most importantly, in determining the number and caliber of personnel initially hired.

${ }^{20}$ For a discussion of the results of replacing the strict profit-oriented assumption with professional ideals and a desire to serve, see text accompanying notes 133-38 infra.

${ }_{21}$ The assumption is that such changes are "no longer" possible because the service providers have already organized their work processes to take advantage of any cost savings and efficiencies that could be realized. 
in service quality cannot measurably increase revenues immediately because these improvements do not register instantaneously in the quality-comparison process of consumers. For the time being, few realize that the producer has upgraded his service; conversely, no one knows if he cheapens his work. This process would appear to create a strong incentive to cut quality and capitalize on the consumer's inability to predict such changes in advance. Obviously, however, because consumers have memories and share experiences with one another, the service providers' optimal production strategy cannot be derived in such a simplistic fashion. In order to tell if quality changes will be profitable, producers are forced to make current decisions about the quality of service to offer based on the impact of such decisions on future revenues. ${ }^{22}$

Before proceeding with an attempt to predict and categorize different market outcomes, it should be noted that the baseline for comparison is the combination of prices and qualities that would be offered to consumers if the market were not characterized by information impactedness. If information were fully, freely, and equally available to all buyers and sellers, then one would expect to observe a collection of goods of varying prices and qualities being sold, reflecting the true preferences of consumers and the actual costs of sellers. Two important types of deviations from this ideal-designated in this Comment "opportunism" and "deterioration"-should be distinguished. Opportunism occurs when sellers are able to peddle their wares at a higher price than would be the case in a market of fully informed buyers; the sellers are opportunistically taking advantage of their inside information about the product's true characteristics. ${ }^{23}$ Deterioration occurs when the overall conglomeration of services offered has on the average a distinctly lower quality than one would expect under more fully informed conditions. ${ }^{24}$

\section{Categorizing Information-Impacted Markets}

Accurate prepurchase inspection input into the consumer's quality assessments typically is unavailable in four essentially

${ }^{22}$ Formally, the producer will compare the present cost or saving caused by a technique adjustment with the increase or decrease in the present value of the expected future stream of revenues. A one-time change in output quality will affect his revenues for many time periods to come.

${ }^{23}$ See, e.g., O. Williamson, supra note 5, at 26; Scitovsky, Ignorance as a Source of Oligopoly Power, 40 AM. Econ. REv. 48 (1950).

${ }_{24}$ For an excellent discussion of the deterioration process in markets characterized by consumer inability to assess quality, see Akerlof, supra note 9. 
different types of information-impacted markets. In the first situation, service providers find that the revenue consequences of quality changes are almost as rapid and substantial as in fully informed markets. The necessary conditions for this outcome are that the consumers of the service make accurate assessments after performance, buy the service with some significant frequency, share useful insights with others, face a stable group of sellers, and possess positive hunches about this service market in general. In this type of market, herein referred to as a "rich experiences" market, quality changes are quickly perceived by purchasers, these insights are soon transmitted to others who are willing to act on them because of their low-risk perception of the market as a whole, and the net results are felt swiftly by sellers who depend on repeat customers for their frequently needed services. Thus the consumer's initial inability to assess service quality by prepurchase inspection leads to very little expected deviation from the price-quality combinations that would obtain under full information.

In the second type of information-impacted market, although consumers can make accurate quality assessments after purchase, several obstacles may prevent them from accumulating the storehouse of experiences that makes the "rich experiences" market approximate closely the fully informed ideal. If, for example, the service is purchased only rarely, is so personalized that other opinions are not very informative, ${ }^{25}$ is sold by sellers who come and go with great rapidity, or generally has such a dubious quality reputation that experimenting is viewed by consumers as being very risky, ${ }^{26}$ then the link for the service provider between today's quality and tomorrow's revenue is greatly weakened. Because consumer reaction to quality changes is less marked than in the "rich experiences" market, service providers in these "limited experiences" markets find it significantly more profitable to cut quality (less loss of customers) and less profitable to increase quality (less gain of customers) than in a fully informed market. This change leads to some overall

25 The usefulness of others' opinions varies dramatically across products, from those items such as gifts, dinner parties, and certain clothes, in which personal'satisfaction may largely depend on the impression the product makes on other people, to very personal services, such as those involving confidential advice seeking and individual tastes in food and travel, in which one may find only his own assessments meaningful.

${ }^{26}$ Numerous market researchers have found that consumer perception that a marketplace is risky tends to discourage sampling of different brands and encourage repeat buying. See, e.g., Cunningham, Perceived Risk and Brand Logalty, in Risk TAking AND Information Handling in Consumer Behavior 507 (D. Cox ed. 1967); $c f$. Roselius, Consumer Rankings of Risk Reduction Methods, 35 J. MARKETING, Jan. 1971, at 56. 
quality cutting (deterioration) along with many successful efforts to disguise these cuts from individual consumers and maintain prequality-decline prices (opportunism).

More severe consumer problems develop in markets in which quality cannot be assessed adequately even after purchase and "use." The consumer's inability to make accurate judgments, however, does not prevent him from arriving at some sort of sweeping conclusion about whether a particular seller performs "good work" for the price he charges. Because the complexity of the situation and his limited understanding prevent him from gaining meaningful information about the relevant quality traits of the service, the consumer utilizes his reaction to revise his response to various observed cues, particularly the seller's name. This extensive use of cues, especially brand names, creates a special type of link for service providers between today's quality and tomorrow's revenue in these "cuereliant" markets. If a service provider wishes to instill a favorable cue response-to gain a "good name"-then he must send his customers home well satisfied with what they received. Thus an underlying set of positive experiences is necessary to create and maintain the desired customer loyalty vital to profits in "cuereliant" markets. Once a significantly favorable reaction to the brand name and other cues has been created, loyal customers consider the product superior to others on the market and are willing to pay a higher price than the true quality might warrant, at least so long as their cue responses are reinforced by general impressions of quality service. ${ }^{27}$ Accordingly, one may conclude that "cue-reliant" markets are characterized by substantial opportunism, but not much deterioration.

Finally, in the most severe circumstances, the market constitutes an amalgam of these last two examples. Consumers are unable to make accurate judgments about past quality and also have a very weak set of cue responses. This may occur either because cues have been suppressed or limited by seller regulations or business practices, or because circumstances analogous to those found in "limited experiences" markets preclude consumers from gaining a sufficiently broad set of cue responses to enable them to make even superficial distinctions among most

${ }^{27}$ For commentary on how adyertising increases reliance on name brands and creates a willingness to pay higher prices, see S. MARgolius, supra note 2, at 15-16. But see Nelson, The Economic Consequences of Advertising, $48 \mathrm{~J}$. Bus. 213-17 (1975). Notice that Margolius, a staunch consumer advocate, criticizes these nationally advertised brands for being overpriced, not for reflecting poor quality. This comports with the proffered analysis that cue-reliant markets are characterized primarily by opportunism. 
sellers. In these "blind" markets, the combination of the consumers' inability to perceive differences and their limited awareness of alternatives beyond those personally sampled on an infrequent basis drastically weakens the link for service providers between today's quality and tomorrow's revenue. Service providers have virtually no incentive to build their reputations as high-quality sellers, and they quickly determine that it is more profitable gradually to cheapen their services. To the extent prices can be maintained for a time, substantial opportunism exists, but the primary result of the situation is that "blind" markets exhibit extreme deterioration. If as time passes the lower quality further reduces consumers' general hunches about the value of this service, consumers may seek substitutes for the service, ${ }^{28}$ and the deterioration process may thus reduce significantly the size of the market as well as the quality of what is sold. $^{29}$

\section{Obstacles to Voluntary Insurance}

Thus, three of the information-impacted service markets - "limited experience," "cue reliant," and "blind"-are likely to pose substantial opportunism and deterioration problems for consumers. As a result, one might want to demand immediately an implied guarantee rule that would force service providers to compensate consumers who purchase substandard quality services in any of these difficult circumstances. Before recommending any legal interference with these admittedly information-impacted transactions, however, one must recognize that the parties themselves are perfectly free to adopt any number of strategies that may alter some of the conditions and predictions suggested by the proposed market models. Above all, service suppliers could voluntarily offer to insure or guarantee their work if they believe that such an approach would attract consumers concerned about the many uncertainties they face in selecting a reliable service person. Indeed, one might wonder

${ }^{28}$ There may be far more choices of this type than one at first glance imagines because of various "no-service" possibilities, for example, feeling poorly and letting nature take its course instead of seeing a doctor or prematurely trading in a car to avoid frequent reliance on the auto repair market. Similarly, an ABA survey suggests that one of the primary reasons that average Americans do not seek legal advice when problems occur is fear that they will not be able to find a lawyer competent to deal with their particular problem. See Dennenberg, To Play Game of Life, You Must Know the Law, Philadelphia Sunday Bulletin, Jan. 25, 1976, $\$ 6$, at 2, col. 4 .

${ }^{29} \mathrm{Fo}$ an analogous model relating consumer inability to perceive quality differences to quality decline and ultimately to the discouragement of those who could otherwise be satisfied customers, see Akerlof, supra note 9 . 
why such guarantees do not emerge naturally in free markets if consumers truly desire them. To answer this question, it is necessary to analyze carefully how such voluntary insurance would operate in the types of markets discussed.

If a service supplier enacts a "performance guaranteed" policy, whereby he promises to redo, free of charge, any services falling below a certain quality level, he would have to raise his price somewhat to cover the cost of redoing initially unsuccessful services. ${ }^{30}$ Consumers who prefer to avoid the risk of "getting stuck" with bad services by paying this price increment would patronize his business. He could not exploit the consumer's desire to avoid risk, however, because another service provider could follow with a similar guarantee at a lower price. Thus, if the first guaranteed policy attracts enough risk averse consumers to push the price of insured services up by $\$ 100$ per week while the cost of honoring the guarantee is only $\$ 50$ per week, then other producers would shift into the insured market and underbid the original policy innovator. Eventually, enough producers should shift into the insured portion of the market so that no special profits would be earned by those offering guarantees, and the benefits of these guarantees would fall to the risk averse consumers.

The decision to offer insurance voluntarily has another desirable result: those suppliers who offer guarantees would bear initially the cost of unsatisfactory services, instead of letting it fall on their unlucky customers. ${ }^{31}$ These suppliers would therefore be motivated to improve the quality of their services at least as long as the cost of extra care and effort is less than the amount saved by providing fewer free replacements. They would not necessarily make their services "as carefully as possible," but rather as carefully as efficiency allowed. Accordingly, if an upgrading of technique entails costs far exceeding the benefits to the service provider as measured by the reduction in the expense of free reservicings, then even suppliers who insure their output would not be motivated to make such quality im-

${ }^{30} \mathrm{He}$ could also offer to pay for any damages caused by the unsatisfactory service, although that would, of course, necessitate an even greater price increase. The ensuing analysis is stated solely in replacement cost terms, but the inclusion of consequential damages would only alter the size, and not the direction, of the forces subsequently discussed.

31 Obviously, the seller eventually will try to pass this cost on to the consumer. See text accompanying note 30 supra. That passing on, however, presents its own market problems, which are addressed subsequently in this section. See text accompanying notes 31-33 infra. 
provements. Nonetheless, the model suggests that voluntary insurance should dampen to some extent the tendency to quality deterioration in these markets.

Unfortunately, several major obstacles prevent the voluntarily insured portion of the market from operating as well as the foregoing would indicate. The enforcement of guarantees is a costly process for both consumers and sellers. Because of the transaction costs incurred in asserting his rights under the guarantee, the consumer cannot consider the offer to redo inadequate service as truly equivalent to the full benefits of an adequate initial service. He must take such steps as complaining, returning himself and perhaps some repairable durable good to the service supplier's location, or, at the very least, doing without the desired service for a time-all of which lower the value of the guarantee. Similarly, in many cases there may be substantial transaction costs in determining whether the service in question meets the standard promised by the guarantee. To compensate for this cost, a burden that formally must be borne by the service supplier ${ }^{32}$ if he adopts a guarantee policy, the seller must charge more than simply the amount needed to cover the replacements he would have to make. This additional price increment, combined with the consumer's concern about the costs that he must bear directly to assert his guarantee rights, would definitely reduce the voluntarily insured portion of the market.

The transaction cost of determining whether the service provided met the promised standard raises another important problem that has not been explicitly discussed. Sellers could reduce this cost almost to zero if they decided to guarantee "full satisfaction," to accept the consumer at his word and automatically provide refunds or reservicing on demand. Such an approach, however, would magnify the two problems classically present in insurance-adverse selection and moral hazard ${ }^{33}$ -

${ }^{32}$ To be able to make these determinations, the seller may need to pay the costs of employing a complaint department, traveling adjusters and inspectors, and other personnel.

33 "Moral hazard" arises when the insurance scheme necessarily reduces a person's incentives to guard against the undesired result. For example, if defense contractors are insured by government agents against increases in their costs over the amount specified in the original contract, then they may not exert a maximum effort to prevent such cost increases. "Adverse selection" occurs when the population knows more about its essential risk characteristics than the insurer, so that mainly high risk types buy insurance. If the life insurance companies dropped their age restrictions and medical examination requirements, they could expect a flood of people with terminal illnesses at their doors to purchase additional life insurance. See K. Arrow, supra note 9, at 142-43; Aker!of, supra note 9 , at $492-94$. 
by increasing greatly the extent to which the consumer's behavior can affect his ultimate satisfaction with the service he receives. For example, although maintenance work on a durable good may be unsatisfactory because of its short useful life, surely the consumer's manner of using the good is itself a major element $i_{x 1}$ determining how long he can wait until he again needs maintenance service. Guarantees containing limitations, such as on manner of use or time during which they will be honored, are basically efforts to reduce the consumer's influence on the warranteed portion of the flow of services that results from the service provider's own work.

In short, full satisfaction offers introduce the moral hazard problem by diminishing the consumer's incentive to take appropriate steps to increase his satisfaction with the service received. To a lesser extent, such offers also introduce the adverse selection problem by encouraging those very customers who will exploit sucil guarantees, thus making them losing propositions for the sellers, to take advantage of insured services. Appliance manufacturers have indicated that this very combination of problems deters them from voluntarily offering more substantial warranties, particularly because they perceive such a significant range of potential customer abuse of their product. ${ }^{34}$ Although this particular problem may be less substantial in many service markets, the general moral hazard danger, combined with the transaction costs discussed above, may reduce decisively the scope of the insured portion of the total market. Thus, the voluntarily insured portion of the market may often be quite small, perhaps even nonexistent, despite consumers' real desire to avoid the uncertainties of uninformed buying and their willingness to pay a premium for some type of guarantee.

\section{E. Providing Information as a Competitive Strategy}

In addition to innovating by offering voluntary guarantees, sellers and buyers have other possible marketing strategies open to them, particularly a frontal attack on the problem of information impactedness. Some of the leading economists who have analyzed information problems have concluded that the natural motivations of producers impel them to provide freely a great deal of information to consumers, ${ }^{35}$ thereby dis-

${ }^{34}$ See federal Trade Comm'n, Report of the Task force on Appliance Warranties and SERvice 80-82 (1969).

${ }^{35}$ See, e.g., R. Posner, Regulation of Advertising by the FTC 3-4 (1973); Stigler, supra note 9 , at 223-24. 
sipating the undesirable effects of information impactedness.

For example, Stigler asserts, "From the manufacturer's viewpoint, uncertainty concerning his price is clearly disadvantageous. The cost of search is a cost of purchase, and consumption will therefore be smaller . . ."36 Thus, the more consumers must spend on finding out what and from whom to buy, the less they will spend on actually buying it. Similarly, Posner concludes that sellers will pay the cost of spreading information so long as the amount they spend is less than the aggregate amount their information dissemination saves consumers in search costs, because by doing so the total cost of the product declines, and, consequently, consumers will purchase more of it. $^{37}$ This line of reasoning suggests that the initial information impactedness characterizing a market would soon be eliminated by producers hurrying to tell consumers about their services. If there is information of positive value to potential customers, then presumably those sellers who lag behind in the disclosure race would suffer major competitive disadvantages. Consumers would choose primarily from among familiar brands, rather than investing from scratch in basic and costly information about unknown sources of supply that could only be presumed to be somewhere in the market.

The foregoing analysis, however, implicitly assumes that all of the information provided by sellers will be accurate and helpful. In the type of service markets being analyzed here, in which even the service providers can make only probability statements concerning their output and in which information about real quality attributes is very limited, serious doubt exists that producer claims can be verified effectively by consumers. Further, although suppliers may be interested in freely offering precise "access facts" such as location, hours, and available services, they would be motivated to make more nebulous statements concerning the underlying quality features that are hidden from consumers in information-impacted situations. ${ }^{38}$ Sellers would find it very awkward to advertise their service

${ }^{36}$ Stigler, supra note 9, at 223.

${ }^{37} \mathrm{R}$. POSNER, supra note 35 , at 4.

${ }^{38}$ This distinction between types of information explains the difference between the conclusion here and that put forward by Stigler, supra note 9, at 224. His analysis might well be an accurate model of the incentives to provide "access facts," but such a prediction surely cannot lead to the expectation that the essential information-related problems of consumers would be eliminated by such data, because buyers would still lack basic quality information. Stigler does, however, acknowledge that he purposely avoided attempting to analyze the search for quality information. Id. 
as "only $6 \%$ defective." 39 It is likely, therefore, that the information imparted would be much the same, and about as helpful, as that which current advertising provides. Even if precise quality-related statements are made, the consumer still faces a task of near statistical impossibility in determining which producers have made valid claims of a meaningfully superior service. The problem is tremendously compounded if the consumer cannot make accurate postpurchase quality assessments, because that inability eliminates his best reference point for testing producer claims. Recognition of these considerations has led several commentators, including some who believe that the marketplace normally can discipline those who make promises and do not keep them, to agree that if consumers cannot judge accurately the effectiveness of different producers, even in the long run, then sellers are likely to make exaggerated claims concerning the qualities of what they are selling. ${ }^{40}$

Therefore, although the motive to supply information to reduce consumers' search costs does exist, the validity and completeness of the information that will be provided are suspect, at least with regard to information that goes beyond "access facts." This analysis suggests that there is no reason to believe that information provided by sellers will alleviate fundamental information impactedness conditions or affect the validity of the market predictions advanced herein. ${ }^{41}$

\section{F. Repeat Buying as a Consumer Strategy}

The main consumer strategy that could alleviate some of the problems of information impactedness is simply spending the time and effort required to become more informed. There are substantial costs involved, of course, in learning more about either what the market has to offer-who the sellers are, how good they are, how much they charge, and so on-or the intrinsic qualities of a particular service. Unfortunately, the same underlying conditions initially creating information-impacted markets also tend to discourage consumers from trying to learn more by prepurchase investigaiions or by sampling differ-

${ }^{39}$ Cf. Franklin, When Worlds Collide: Liability Theories and Disclaimers in DefectiveProduct Cases, 18 STAN. L. Rev. 974, 1017 (1966) ("[C]urrent marketing and advertising philosophy is not calculated to operate in a posture of lucid warnings and disclaimers.").

${ }^{\text {to }}$ See, e.g., R. PosNer, supra note 35, at 4-5; Darby \& Karni, supra note 17, at 68-72. But see Nelson, supra note 27.

${ }^{41}$ For a very strong statement of the position that, on balance, information supplied by producers aggravates consumer information problems and multiplies opportunism, see S. MARGolius, supra note 2, at 12-24. 
ent brands, behaviors referred to in this Comment as "search" and "experience sampling," respectively. ${ }^{42}$ For example, even though search greatly enhances the consumer's information in markets for important purchases such as appliances and housing, the crucial problems that consumers confront in gaining valid information from prepurchase inspections practically eliminate the incentive to engage in search behavior in service markets. The service consumer's principal motivation for search comes from his responsiveness to inspection-related cues; his responses may afford him a sense that he has truly sharpened his quality assessment by visiting the service provider's premises. ${ }^{43}$ Clearly, traditional prepurchase "shopping around" cannot be expected to play any significant role in reducing the type of information deficiencies that are the focus here.

Predicting consumers' experience sampling behavior requires reference to the four different categories of information impacted markets described above. The extent to which such behavior was and could be utilized was implicitly a vital criterion in making the distinctions between market types. ${ }^{44}$ The consumer in limited experiences circumstances has very little information about products that he has not personally sampled. $\mathrm{He}$ might, therefore, seem likely to engage in extensive experience sampling as his only real avenue to an informed choice: If, however, his general hunch about that service market as a whole is quite low-for example, perhaps he believes that most auto mechanics are unreliable-then he will be deterred from further sampling once he has located an acceptable service supplier. ${ }^{45}$ Similarly, consumers reacting to brand names in cuereliant markets are unlikely to bear the expected cost of experience sampling once they have developed and reinforced a strorg positive cue response to a favorite seller. On the other hand, consumers in rich experiences markets, those in limited experiences markets who curtailed their experiences for reasons other than pessimism, and those in cue-reliant markets

42 For the origins of this terminology, see Nelson, supra note 9, at 312. Nelson's concepts of the relevant costs and benefits of different modes of information gather ing have been simplified for application to this model. See id. 313-15.

${ }^{43}$ The incentive to search depends in part on the probability that such activity will lead to a modification of the purchase choice that would have been made prior to such search. Id. 313. Thus the response to cues, which often cause the consumer to alter his purchase preference, can be jus: as great an incentive to search as are valid inspections.

${ }^{44}$ The two basic differences between rich experiences and limited experiences markets, for example, are the predicted extent of experience sampling and the range of contacts with other consumers. See notes 25-26 supra \& accompanying text.

${ }^{45}$ See sources cited at note 26 supra. 
who primarily respond to cues other than name are not likely to display the same degree of brand-loyal buying. Only in the rich experiences market, however, does experience sampling reduce substantially normal information impactedness problems. ${ }^{46}$

The strength of the incentives for consumers to replace experience sampling with a pattern of brand loyal buying ${ }^{47}$ can be better appreciated by focusing momentarily on blind markets. Consumers in such situations can be expected to recognize not only their own minimal ability to distinguish meaningfully among sellers, but also that service providers possess a special advantage because their product is produced on demand for a particular customer. Although all television sets of a given model made by any one manufacturer in one month or possibly even one year are likely to have been built very similarly, the service supplier can vary dramaically the care and intensity of his efforts as each new customer walks through the door. The chances for opportunism multiply fantastically when the seller can make individual determinations about the knowledgeability and long run expected worth of each customer, instead of having to fix a single marketing strategy in advance.

The consumer has only one real bargaining chip in this situation: the potential to become a valuable customer by repeatedly patronizing the same service supplier. ${ }^{48}$ When the service provider senses this possibility he can be expected to curtail some of his opportunistic behavior in order to maintain the stream of future business the customer represents. On the other hand, consumers who emit signals indicating a low probability of becoming a return customer-an out of state license plate, a neglected good that shows regular maintenance is not sought-

${ }^{46}$ For example, those in limited experiences markets who are unaware of the attributes of many sellers because of low frequency of purchase may not display brand loyal buying patterns, but they are still subjected to the deterioration and opportunism predicted to characterize such markets. The rich experiences circumstances remain the only ones in which impactedness problems will be alleviated naturally.

${ }^{47}$ These predictions of consumer behavior are essentially an application of a type of organizational analysis developed in O. WiLliamson, supra note 5, at 20-40. Williamson discusses the frequent tendency of economic agents involved in repeat transactions to develop organizational modes offering substantial advantages for both parties by departing from true market contracting behavior. In the analysis that follows, the consumers gain such advantages by practically ceasing to play the role expected of active consumers in a market system and, in a sense, "joining" the business firm as a regular part of the total organization.

${ }^{48}$ For a slightly different explanation of the development of client-type relationships as a "solution" for customers in markets highly susceptible to fraud, see Darby \& Karni, supra note 17 , at $80-81$. 
may face significantly more exploitative seller behavior. The desire to reduce seller opportunism, however, is only one of the forces impelling consumers to forego experience sampling and become steady clients of a service provider. For example, many services involve elements of personal diagnosis or adjustments that can be done much more efficiently by people who have previously performed the service for that customer. ${ }^{49}$ Further, many people place a positive value on the personalized relationships that can be developed over time between service provider and consumer. ${ }^{50}$ Thus, with the exception of those in the favorable setting of rich experiences markets, most consumers are unlikely to find manageable personal strategies to overcome information impactedness. ${ }^{51}$ They will tend instead to search and engage in experience sampling only until they locate a seller whose price-quality offering is acceptable and whose regular client they can become.

\section{Application of the Model: Choosing the}

Appropriate Legal Rule for Particular Service Markets-A Decisional Framework for the CoUrts

\section{A. The Impact of Implied Guarantees}

The foregoing has indicated that ininerent market forces limit severely the availability of voluntarily insured services, preclude dissemination of a substantial quantity of reliable information concerning service quality, and induce much habitual and uninformed buying. On balance, the self-interested strategies of consumers and sellers increase the potential avenues for

${ }^{49}$ Efficiencies may be realized in the time sense of not having to explain to a customary service provider precisely how one's hair should be cut or what type of cleaning work needs to be done. More importantly, however, efficiencies in terms of better performance for the price may be realized because the customer cannot successfully articulate his needs or desires to a new service person at a first meeting as well as he can gradually communicate them over time. Moreover, problems may exist that the service provider is called upon to fix that can only by diagnosed accurately by someone with long term familiarity with the object needing repair.

${ }^{50}$ These types of personal preferences for one "style" of contracting over another on primarily noneconomic grounds are referred to by Williamson as "atmosphere." See O. Williamson, supra note 5 , at 37 . Such advantages could easily be so strong in some service markets, especially those in which much confidential information must be conveyed to the service provider, that even the most knowledgeable consumers may strongly prefer to establish client-type relationships.

${ }^{31}$ Both aspects of the client relationship's impact on information impactedness problems must be recognized. Consumers may understandably decide to become clients in order to limit or check opportunism, but their desire to maintain such relationships also exposes them to such opportunism because they have withdrawn from the market and are no longer making any precise comparisons between sellers. 
seller opportunism and reduce only minimally the quality deterioration identified as the potential outcomes in the "limited experiences,"52 "cue-reliant,"53 and "blind"54 markets. With no reasonable expectation, then, of a "natural cure" for information impactedness-related problems, ${ }^{55}$ the next crucial question is the impact of various legal rules of implied guarantees on these types of markets. The effect of such rules will vary not only with the strictness of the rule-the extent to which it shifts the costs of consumer dissatisfaction and injury back to sellers and producers-but also with the manner in which the rule operates. The key distinction in this latter regard is between rules that determine liability by assessing the activities of the service provider, such as a negligence rule and its required standard of care, and rules that determine liability by focusing on the characteristics of the product or service itself, such as an implied warranty rule and its merchantability test.

\section{Combating Deterioration and Opportunism}

Effort-oriented rules, such as the traditional negligence standard, modify the reward structure of service providers. In the absence of any legally implied guarantee, a service provider can assess planned technique changes involving less careful service production simply by comparing the possible loss of customers caused by lower quality output with the savings realized by using less expensive methods of service performance. With an implied guarantee rule in effect, however, he must consider the additional cost of court-imposed damage payments if dissatisfied customers can show that his efforts did not meet the legal standard. His choice of techniques is not significantly affected by the imposition of a liability rule until he begins to consider utilizing techniques involving a level of effort near or below the legal standard; ${ }^{56}$ the potential imposition of damage payments generally makes it unprofitable for service providers to regularly select production techniques at or below the stan-

${ }^{52}$ See text accompanying notes 25-26 supra.

${ }^{53}$ See text accompanying note 27 supra.

${ }^{54}$ See text accompanying notes $28-29$ supra.

5s But see O. Williamson, supra note 5, at 26-28, 31-33. Recall the statement at the outset that the model developed here arrives at divergent conclusions from many of the major sources of the concepts employed in this analysis. See note 9 supra. This conclusion about the limits of the competitive mechanism is perhaps one of the most important of such differences.

${ }^{36}$ Producers may have difficulty knowing with certainty whether a given level of effort is likely to be adjudged as a breach of the standard, but the motivation provided by the rule will be operable as long as they can distinguish different techniques according to the rough probability of incurring liability. 
dard. Thus, the introduction of an effort-oriented implied guarantee rule provides a floor under the quality deterioration expected in information-impacted markets. Moreover, if the level of legally required effort is set very high, producers would be forced either to improve the carefulness with which they provide services or to drop out of the market entirely. ${ }^{57}$

Outcome-oriented rules may have slightly more complex effects on expected marketplace results. Imposition of a legal standard for output quality may curb deterioration because service providers would be deterred from choosing techniques likely to produce a high percentage of services that fail to fulfill the legally required minimum quality. In comparison to effortoriented rules, outcome rules may provide a firmer floor under deterioration because the dissatisfied customer must show only that he received a poor quality service, whereas under an effortoriented rule he ordinarily must demonstrate both that he was damaged by a poor quality service and that the service provider failed to expend the legally required effort. If the outcome rule assumes a slightly more complicated form, such as an implied warranty of merchantability, ${ }^{58}$ then it may also curb some opportunism by service providers, although offering less resistance to quality deterioration. The key to these effects in a given situation is defining merchantability with reference to the price paid by the consumer. ${ }^{59}$ Accordingly, if producers cut their prices they could effectuate corresponding quality decreases without confronting the threat of legally imposed refunds and damages awards. Courts would, for example, be able to hold that a customer received a merchantable ten dollar repair job because he "got what he paid for," even if the repair work was shoddily performed by some other standard. Similarly, at

57 The level of legally required effort does not have to be expressed in terms of a "reasonable man" or "prevailing standards of practice." Although this discussion basically proceeds with a view toward the familiar negligence standard as the prime effortoriented rule, analytically the effort standard could be set higher ("all feasible cautions"), or lower ("no reckless production techniques").

${ }^{58}$ UNiform CoMmercial CODE § 2-314.

${ }^{39}$ For example, a West Virgina court disposed of a situation in which a generally knowledgeable buyer paid about half of the usual price for some coking coal and then sought to recover for breach of an implied warranty of merchantability because the ash content was too high, stating, "[T]he nature and scope of an implied warranty of merchantability, which is a concept relating to overall quality rather than fitness for a particular purpose, are excellently outlined by consideration of the selling price." Sylvia Coal Co. v. Mercury Coal \& Coke Co., 151 W. Va. 818, 828, 156 S.E.2d 1, 7 (1967). The court cited an official comment in the West Virginia codification of the UCC, $W$. VA. Code ANN. \& 46-2-314 (Michie 1966), Comment 7, for this proposition. Id, at 827, 156 S.E.2d at 7. 
higher prices service providers would recognize that they might face legal liability if they marketed mediocre services; their output might not constitute "merchantable top calibre" service work. Thus, an outcome rule of the merchantability type could limit opportunism by imposing liability on sellers for quality deviating from reasonable consumer expectations generated by the price, whereas an effort-oriented rule would primarily address deterioration by focusing on the efforts expended by the service provider.

Both effort-oriented and outcome-oriented rules, however, are more likely to be successful in curbing quality deterioration than in discouraging seller opportunism. For example, a merchantability rule that honors pricing signals is unlikely to curtail modest forms of opportunism, such as charging slightly above average prices for merely average quality. In what is supposedly a system based on free markets, the realities of the judicial process make the courts an inappropriate vehicle to impose precise quality fine tuning sufficient to meet this problem. ${ }^{60}$ More fundamentally, deterioration and opportunism pose markedly different detection problems for consumers. If a person is troubled by deterioration in the quality of a service, he can bring suit and allow the courts to determine whether the service provider failed to make the requisite efforts or meet the appropriate output standards. Much opportunism occurs, however, when people who are generally satisfied-or perhaps even well pleased-with a service pay a premium for it that they would not have paid in a more fully informed marketplace. Although outside observers may perceive the problem, those making the purchase may be perfectly content. ${ }^{61}$ One familiar manifestation of such opportunism is the performance of unneeded repair or restorative services in the course of remedying a relatively simple malfunction. ${ }^{62}$ The customer departs rea-

${ }^{60}$ The courts could calibrate a quality scale for every product and service and define a complete set of standards necessary, for example, for a merchantable \$20 brake job, $\$ 30$ brake job, and $\$ 40$ brake job, but such an endeavor would give the courts almost absolute power over the terms of the bargains struck in the marketplace, a concept completely inconsistent with even the most rudimentary notion of freedom of contract.

${ }^{61}$ Recall that cue-reliant consumers will come to believe that their favorite brand is actually better and hence freely subject themselves to a substantial amount of opportunistic exploitation. See text accompanying note 27 supra. For examples that indicate the strength of such cue-related preferences, even in the face of data showing the physical and chemical equivalence of competing brands, see S. Margolius, supra note 2, at 14-16.

${ }^{62}$ For a model of repair markets that focuses on the problem of performing unneeded services, see Darby \& Karni, supra note 17. 
sonably content because his problem has been remedied. He may never realize that he actually paid much more than the problem demanded. To the extent that the lack of consumer information shields this situation from the view of those who are "victimized," neither marketplace discipline in the form of dissatisfied customers taking their business elsewhere nor legal imposition of an implied guarantee is likely to offer much relief.

\section{Other Key Features of Implied Guarantees}

Having recognized the impact of a proposed legal guarantee rule on the information impactedness-related problems of deterioration and opportunism, other key features of implied guarantee rules should be considered before recommending particular rules for certain markets. A second element is the imposition of substantial transaction costs when a consumer who believes he has been injured asserts the rights theoretically provided by a legally implied guarantee. The process of adjudicating a violation of the legal standard and determining the concomitant damages involves substantial costs for the consumer, the service provider, and society at large. If market forces alone could police effectively producer behavior, or if some simpler means of introducing a floor under quality deterioration or combating seller opportunism could be found, then significant savings could be realized on these legal transaction costs. ${ }^{63}$ Even more importantly, if the transaction costs the unhappy consumer must bear to redress his grievance become too great, he may decline to press his complaint, vitiating the legal rule's power to curb deterioration and opportunism. ${ }^{64}$

A third feature of implied guarantee rules is the potential introduction of some very peculiar inefficiencies into both the provision and consumption of services. The outcome standard saddles the producer with the damages costs of practically all defective services. The service producer therefore possesses a strong incentive to implement technologically available and cost efficient technique changes. The benefits of improvements in technique may be measured in part by the reduction in servicerelated damages caused by production of better quality services. Effort-oriented legal standards, on the other hand, may per-

${ }^{63}$ For an explanation of the potential economies involved in relying on market forces, see McKean, Products Liability: Trends and Implications, 38 U. CHI. L. Rev. 3, 44-45 (1970).

${ }^{64}$ For a discussion of this problem in the context of no-fault plans as a possible solution in the area of medical malpractice, see J. O'CONNELL, ENDING INSULT To INJURY 29-44 (1975). 
petuate or create inefficiencies because producers are held liable for damages only if their efforts fall short of some prescribed standards. If the producer's efforts already safely exceed the legal minimum, he may disregard socially efficient improvements because the benefits will inure only to his customers. Even more perversely, effort-related rules may motivate producers to adopt more expensive techniques that produce relatively small social benefits in the form of reduced damages, but that are individually extremely profitable to the individual producer because they lift his efforts safely above the legally established standard. Indeed, this very response is the essence of the current controversy over so-called "defensive medicine." 65 Some observers believe that many doctors now prescribe tests and treatments that they would not otherwise recommend, primarily because these additional measures enhance the doctor's defense against a subsequent malpractice action brought by a dissatisfied patient. Surely the real possibility that an effortrelated standard can be the cause of producer inefficiency must be considered in assessing the desirability of various legal rules.

The legal rule for implied guarantees can also have efficiency-related effects on consumer behavior. Despite consumers' limited overall knowledge, consumers do possess some important personal information that may have a substantial impact on ultimate product satisfaction. ${ }^{66}$ Moreover, certain relevant marketplace information may aid consumers who expend the necessary time and effort to learn about prospective purchases. ${ }^{67}$ Given these underlying circumstances, in minimizing the occurrence of marketplace discontent care must be taken to avoid shifting the responsibility and cost of all such dissatisfaction to producers or sellers. A total shift would reduce the incentives for consumers to institute socially efficient (cost less than benefits) actions to protect themselves. Thus retailers who guarantee "money back if not perfectly satisfied" may reduce to some extent customer incentive to shop around, carefully examining items, or to use the product carefully to extend its useful life. This problem is closely analogous to the moral

${ }^{65}$ See id. See generally R. Titmuss, The Gifr Relationship 168-69 (1971).

${ }^{66}$ Consumers have special knowledge of their own particular needs. This may be crucial in determining if a certain type of therapy, investment advice, or other service is ultimately satisfactory. The costs of transferring such internalized, satisfaction-related information may be demonstrated by the difficulties frequently encountered in giving someone else instructions sufficient to make an acceptable purchase of many types of goods and services.

${ }^{67}$ See notes $42-43$ supra \& accompanying text. 
hazard and adverse selection problems that would operate to reduce the feasibility of voluntary insurance by service providers. ${ }^{68}$ Thus, incentives to inefficiency possibly generated by particular legally implied guarantees must be considered on both the producer and the consumer side of the transaction.

The fourth crucial general effect of legally implied guarantee rules is a potential reduction in marketplace choices. If effective, implied guarantee rules would drive certain previously available choices off the market by judicially imposing intolerably heavy damage awards. To the extent that a merchantability type of outcome-oriented rule aims at opportunism by allowing low quality to remain on the market if the price is correspondingly low, the elimination of some opportunistic price-quality offerings from the range of available choices appears desirable. Both types of legal standards, however, and particularly effort-related standards, are more likely to be used to combat deterioration by focusing on services frequently failing to produce successful results. ${ }^{69}$ This use is likely to drive off the market some high risk services previously desired by consumers because of their low price or potentially enormous value (such as difficult surgery that could save a life). If the legal standard effectively reduces quality deterioration and forces previously uninsured sellers to employ more careful techniques, consumer welfare may be enhanced; the consequence would be the availability of many alternatives of reasonable quality falling between the prior extremes of a few high-quality insured services and a plethora of uninsured services of dubious quality. For those knowing consumers who previously preferred the high-risk options, however, narrowing their choices would entail decreased welfare. ${ }^{70}$ No general prediction can be advanced concerning the expected result for all services, but anyone recommending particular legal rules must realize that any proposed rule necessarily implies a social decision regarding which pricequality-risk alternatives should remain on the market. ${ }^{71}$ If not selected with this concern in mind, the guarantee rule can err in either of two directions: admitting undesirably risky options or driving out suppliers that many people value and would keep if given the choice.

${ }^{68}$ See note 33 supra \& accompanying text.

${ }^{69}$ See notes 60-62 supra \& accompanying text.

${ }^{70}$ See McKean, supra note 63, at 50-51.

${ }^{71}$ Because the judicial or administrative determination concerning a particular buyer and seller will necessarily affect the marketing decisions of all producers, any such determination will become, in large part, a "social decision." 
Fifth, in addition to the wide range of overall market effects introduced by imposing a legal guarantee rule, it is important to consider that all such rules may not comport equally well with societal notions of individual justice. ${ }^{72}$ For example, regardless of the market desirability of a particular rule, many would characterize it unfair to hold individual service providers liable for damages if they employed maximal skills and technology but nevertheless failed to achieve the desired results. Others would similarly revolt at the notion that an "innocent customer" should ever be left to bear the costs of physical injuries stemming from services performed for him, regardless of the care and intentions of the service provider. Such considerations are significant both because predictions of positive market effects alone are unlikely to produce "better" legal rules and because rules that strongly conflict with traditional social values are unlikely to operate in practice in the intended manner. ${ }^{73}$

\section{B. Preliminary Inquiries and Guidelines for Adjudication}

The economic models and predicted effects of various legal rules articulated in this Comment suggest the types of considerations courts should employ when analyzing cases involving claims against service providers. Before applying these considerations to particular cases, it would be helpful to organize them into a series of key inquiries.

In assessing the applicability of the market models, the first step is to respond to a set of preliminary questions: (1) Information impactedness-Is the situation characterized by information impactedness? (2) Range of techniques-Do the service providers in the market possess a range of techniques from which to choose, with some more likely than others to produce successful results? (3) Profit maximizing-When choosing their production and marketing strategies, are service providers likely to take advantage of their inside information in a basically profit-maximizing fashion? (4) Nonmarket curbs-Is there a

${ }^{72}$ For a closely analogous discussion of combining economic goals with considerations of justice, see G. Calabrest, supra note 9, at 24-31.

73 If legal rules are enacted in the face of such conflicts, the theoretical predictions that led to the enactments are likely to be confounded by the behavior of the real people involved in enforcing such rules. For instance, if strict liability for doctors is predicted to lead to substantial improvements in the quality of care, but society feels that such liability is "not fair," then judges and juries may strain to return verdicts in favor of doctors by expansively interpreting such concepts as assumption of risk in order to shift responsibility back to the patients. 
lack of nonmarket forces (other than implied guarantees) that could curb deterioration and opportunism?

These inquiries are essential to assessing the applicability of the market models detailed above and understanding the role that an implied guarantee can be expected to assume in a particular service market. Although they do not dictate automatically a choice of rules, affirmative responses to them will indicate that the model's basic assumptions and predictions concerning the role of implied guarantees fit the case at hand and that these considerations can be molded into a decisional framework for selecting the appropriate legal rule. A negative response, on the other hand, will be a warning flag that the implied guarantee will not play the normal role suggested by the model and that the decisionmaking process needs to be modified. For example, if a court believes that service providers in a specific circumstance possess no realistic alternative procedures (no range of techniques), ${ }^{74}$ it should recognize that a legally implied guarantee would not alter the reward structure faced by the service providers as they decide how to perform their tasks. Similarly, if major external forces such as a detailed statutory scheme of disclosure requirements (no information impactedness) and output regulations (nonmarket curbs) have previously been injected into the market to limit opportunism or deterioration, the court should sense both that the implied guarantee may not fulfill its usual function of combating information impactedness problems and that deference to the statutory scheme as an expression of legislative intent concerning the shape of this market may be proper. Finally, as shall be stressed in the forthcoming discussion of Broyles $\%$. Brown Engineering $\mathrm{Co}^{75}$ and

${ }^{7 *}$ This issue was discussed in the lower court opinions in Magrine v. Krasnica, 94 N.J. Super. 228, 227 A.2d 539 (Hudson County Ct. 1967), affd sub nom. Magrine v. Spector, 100 N.J. Super. 223, 241 A.2d 637 (App. Div. 1968) (per curiam), aff'd, 53 N.J. 259, 250 A.2d 129 (1969) (per curiam). The county court determined that a dentist should not be held strictly liable for a needle that broke off in his patient's jaw, stressing that one of the key policies motivating strict liability is the belief that sellers are in a better position than buyers to know about and control defects; that is, they have a choice of techniques. $I d$. at 234,227 A.2d at 542 . The court found this rationale inapplicable to the dentist and thus refused to apply strict liability. Id. at 234-35, $227 \mathrm{~A} .2 \mathrm{~d}$ at 543 . On the other hand, the dissenting opinion in the appellate division perceived that some control and choice did exist, insisting: "The dentist should also know the quality of the instrument and the reliability of his source of supply. [Applying strict liability to him] may encourage a greater caution in purchasing equipment and examining for defects." 100 N.J. Super. at 232, 241 A.2d at 642 (Botter, J., dissenting).

${ }^{75} 275$ Ala. 35 , 151 So. $2 d 767$ (1963) (per curiam); see notes 119-38 infra \& accompanying text. 
Newmark v. Gimbel's, Inc. ${ }^{76}$ the court should consider at an early stage the degree to which it believes the service providers are guided by ordinary commercial considerations (profit maximizing) in their choice of techniques in order to gauge the likelihood that a different implied guarantee standard would alter these choices and thereby transform the quality of services available to consumers.

The majority of services regularly purchased pass these preliminary inquiries without even raising any borderline questions, because circumstances such as extensive legislative or peer group regulation and non-commercial motivations are irregular, although present in some highly visible and frequently discussed markets. ${ }^{77}$ Having been sensitized by the preliminary inquiries to any unusual aspects of the implied guarantee's role in the market being investigated, the court then should embark on what is basically a balancing test between negligence and implied warranty rules by utilizing the major considerations outlined previously. The relevant areas of inquiry may be schematized in a question oriented checklist: (1) Impact on opportunism and deterioration-Can one expect a proposed rule to have any impact on particular information-related problems in a specific market? (2) Transaction costs-Are the legal transaction costs associated with a proposed rule unnecessarily great, perhaps sufficiently so to dissuade consumers from seeking to enforce theoretically existing rights? (3) Incentives to inefficiency-Does the rule limit or multiply the natural market incentives for inefficient behavior on the part of producers or consumers? (4) Boundaries on allowable risks-Does the proposed rule construct an appropriate boundary line for the consumer risks that society wishes to see available in the market, driving out the unwanted and preserving those needed or desired? (5) Marketplace justice-Does the proposed standard comport with society's basic notions of marketplace justice?

These considerations are by no means totally foreign to courts previously confronted with implied guarantee questions,

7654 N.J. 585, 258 A.2d 697 (1969); see notes 139-59 infra \& accompanying text.

${ }^{77}$ Focus on the few highly visible services (especially the medical field) in which these unusual circumstances do occur may have seriously slowed advances that could have rightly protected consumers in more everyday situations. The courts justifiable hesitance to abandon the negligence rule in these high visibility professional services may help to explain the many pronouncements and decisions that retarded the extension of warranty concepts in the service area at the same time that such protections were expanding elsewhere. See notes $94-98$ infra \& accompanying text. 
and earlier service cases can be located in which some of these elements have been tacitly or even explicitly recognized. ${ }^{78}$ The courts, however, have lacked consistently a comprehensive set of essential inquiries based on a carefully articulated view of buyer-seller interaction and the impact of legally-implied guarantees upon that interaction. This framework represents an attempt to fill that gap. With the relevant inquiries in mind, representative cases concerning the appropriate legal rule for service markets can be analyzed to demonstrate how the proposed model can assist the courts in dealing with future cases in this evolving area of law.

${ }^{78}$ Information impactedness has been mentioned as a reason to extend implied warranty to some services. See, e.g., Jeffreys v. Hickman, 132 Ill. App. 2d 272, 269 N.E.2d 110 (1971); Hill v. Polar Pantries, 219 S.C. 263, 64 S.E.2d 885 (1951). Perhaps more subtly, one court explicitly denied an implied warranty because the service provider had clearly warned the customer that he really did not know how to achieve the customer's purpose and had gone ahead only at the customer's repeated insistence. Mercedes Dusting Serv., Inc. v. Evans, 353 S.W.2d 894 (Tex. Civ. App. 1962).

Two courts acknowledged that strict liability developed in the goods context in large part to circumvent the enormous legal transaction costs that prevented injured consumers from obtaining redress, but these courts found such difficulties absent in the face-to-face dealings that characterize service markets. This constituted part of the basis for the courts' rejection of the applicability of strict liability to services. La Rossa v. Scientific Design Co., 402 F.2d 937, 942-43 (3d Cir. 1968); Hoffman v. Simplot Aviation, Inc., 97 Idaho 32, 539 P.2d 584,588 (1975).

The incentive-to-inefficiency considerations have not generally permeated service cases, although a Mississippi court did apply strict liability to a plumbing contractor for the installation service he performed, on the grounds that he could have more efficiently prevented the defect than could the original manufacturer, who provided installation instructions ignored by the contractor. State Stove Mfg. Co. v. Hodges, 189 So. 2d 113 (Miss. 1966), cert. denied sub nom. Yates v. Hodges, 386 U.S. 912 (1967). One nonservice case, Kobeckis v. Budzko, 225 A.2d 418 (Me. 1967), in which a consumer put a product to abnormal use, provides a particularly excellent example of a court unwilling to shift the responsibility for injury back to the sellers because such a rule would remove from consumers the obligation to take obviously efficient self-protective measures that are widely known and readily understood.

The risk boundary problem was explicitly discussed in Newmark v. Gimbel's, Inc., 54 N.J. 585, 258 A.2d 697 (1969). See text accompanying note 148 infra. But the classic example of an attempt to deal with this issue is Justice Traynor's opinion in a goods case, Seely v. White Motor Co., 63 Cal. 2d 9, 15-19, 45 Cal. Rptr. 17, 21-24, 403 P.2d 145, 149-52 (1965). Justice Traynor also noted that because the plaintiff could have shopped around for a truck more suitable to his needs, he bore the risk that the product he chose would not meet his expectations, absent an assurance by the manufacturer that it would. Id. at $19,45 \mathrm{Cal}$. Rptr. at 24,403 P.2d at 152 . Under the circumstances, any other risk allocation would have generated inefficiency on the consumer side by dulling the buyer's incentive to shop around. Allowable risk concerns have also motivated other courts to extend implied warranties to services posing special dangers to consumers if not done properly. See Buckeye Union Fire Ins. Co. v. Detroit Edison Co., 38 Mich. App. 325, 330, 196 N.W.2d 316, 318 (1972). But see Chutich v. Samuelson, 187 Colo. 155, 529 P.2d 631 (1974) (en banc), rev'g 33 Colo. App. 195 (1973).

Citations are hardly necessary to demonstrate that courts have considered concepts of individual justice in deciding implied gurantee service cases. 


\section{Judicial Decisionmaking Concerning Appropriate IMPLIED GUARANTEES}

\section{A. The Current State of the Law}

The current majority view is that the extensive implied warranties for the sale of goods outlined in Article 2 of the Uniform Commercial Code ${ }^{79}$ do not apply to service transactions. ${ }^{80}$ The consumer's chances of recovering damages for unsatisfactory services depend instead on his ability to demonstrate negligence by the service provider. ${ }^{81}$ The issue is sometimes confused by the tendency of the courts to speak the language of implied warranties, although characterizing the protection afforded as an "implied warranty of workmanlike performance,"82 which is simply a negligence rule. Typifying this disposition is the court's statement in Garcia v. Color Tile Distributing Co. ${ }^{83}$ describing the responsibility of those providing the service of floor installation:

$[\mathrm{H}]$ aving undertaken to render services in the practice of a skilled trade, [the service provider] impliedly warranted that it would exercise such reasonable degree of skill as the nature of the service required. . . . [T]he degree of care necessarily required by one who undertakes to render services to another in the practice of a trade which is the result of acquired learning, or developed through special training and experience is that which a reasonably prudent man, skilled in such work, would exercise. ${ }^{84}$

In a handful of service cases, courts have articulated or applied an implied warranty theory that transcends the negligence standard ${ }^{85}$ but these cases represent the minority view.

79 UNIFORM COMMERCIAL Code $\$ \S 2-314,-315$.

${ }^{80}$ See, e.g., Howard v. United Fuel Gas Co., 248 F. Supp. 527, 532 (S.D.W. Va. 1965); Audlane Lumber \& Builders Supply, Inc. v. D. E. Britt Associates, Inc., 168 So. 2d 333, 335 (Fla. Dist. Ct. App. 1964), cert. denied, 173 So. 2d 146 (Fla. 1965). For a detailed discussion of the current state of the law in this area and an extensive number of relevant case citations, see Greenfield, Consumer Protection in Service Transactions-Implied Warranties and Strict Liability in Tort, 1974 UTAH L. REv. 661, 663-83.

${ }^{81}$ See, e.g., Pepsi Cola Bottling Co. v. Superior Burner Serv. Co., 427 P.2d 833 (Alas. 1967); Myers v. Ravenna Motors, Inc., 2 Wash. App. 613, 468 P.2d 1012 (1970).

${ }^{82}$ See, e.g., Isthmian Lines, Inc. v. Canadian Stevedoring Co., 216 F. Supp. 856, 861 (D. Ore. 1963); Reliable Elec. Co. v. Clinton Campbell Contractor, Inc., 10 Ariz. App. 371, 374, 459 P.2d 98, 101 (1969); $c f$. Jamison Fertilizer Co. v. White Motor Co., 246 Ore. 610, 425 P.2d 191 (1967).

${ }^{83} 75$ N.M. 570,408 P.2d 145 (1965).

${ }^{84} I d$. at 573,408 P.2d at 148 .

${ }^{85}$ See Aced v. Hobbs-Sesack Plumbing Co., 55 Cal. 2d 573, 584, 360 P.2d 897, 902, 
In the past decade, the significance of implied warranties as a vehicle for recovery by dissatisfied consumers has been substantially reduced by the rapid expansion of the strict liability in tort approach articulated in section 402A of the Restatement (Second) of Torts ${ }^{86}$ and in Greenman v. Yuba Power Products, Inc. ${ }^{87}$ Section 402A explicitly refers to defective "products," and the courts have been nearly unanimous in refusing to extend this concept to service transactions. ${ }^{88}$ The so-called sale-service hybrid cases following the path of Newmark v. Gimbel's, Inc. ${ }^{89}$ suggested the rule that a seller supplying a defective product incident to provision of a service should be held strictly liable for resulting consumer injuries. ${ }^{90}$ Even this proposition has not been universally accepted, however, and many jurisdictions refuse to accept any extension of strict liability to transactions that are predominantly of services. ${ }^{91}$ Moreover, consumers receiving worthless services but not suffering physical injury are often handicapped by the rule that strict liability cannot be used as the basis of recovering economic losses, such as the value of the item purchased. ${ }^{92}$

The conclusion is reached quickly that the current law of implied guarantees offers substantially less protection to consumers of services than it does to consumers of goods. Although service markets are more susceptible than goods markets to the severe information impactedness problems necessitating a legal guarantee rule or some other mechanism to curb deterio-

12 Cal. Rptr. 257, 263 (1961) (warranty implied for labor and materials used in installation of heating system); Jeffreys v. Hickman, 132 Ill. App. 2d 272, 269 N.E.2d 110 (1971) (implied warranty to paint car includes lesser warranty that paint job will endure for a reasonable time); Buckeye Union Fire Ins. Co. v. Detroit Edison Co., 38 Mich. App. 325, 330, 196 N.W.2d 316, 318 (1972) (implied warranty connected with provision of electrical service); McCool v. Hoover Equip. Co., 415 P.2d 954, 958 (Okla. 1966) (service of rechroming crankshafts includes implied warranty that shafts will not fail due to defective chroming).

86 Restatement (Second) of Torts $\$ 402 A$ (1965).

${ }^{87} 59$ Cal. 2d 57, 377 P.2d 897, 27 Cal. Rptr. 697 (1963).

${ }^{88}$ See, e.g., Hoffman v. Simplot Aviation, Inc., 97 Idaho 32, 539 P.2d 584 (1975); Chevron Oil Co. v. Sutton, 85 N.M. 679, 515 P.2d 1283 (1973).

8954 N.J. 585, 258 A.2d 697 (1969).

${ }^{90}$ See Carpenter v. Best's Apparel, Inc., 4 Wash. App. 439, 481 P.2d 924 (1971).

${ }^{91}$ See, e.g., Seely v. White Motor Co., 63 Cal. 2d 9, 403 P.2d 145, 45 Cal. Rptr. 17 (1965). Even the "hybrid" cases, see note 90 supra \& accompanying text, may not apply to the situation in which the service component is "predominant" in the transaction. See Carpenter v. Best's Apparel, Inc., 4 Wash. App. 439, 442-43, 481 P.2d 924, 926 (1971) ("[T]he sale is a hybrid partaking of both a sale and a service . . . [W]e cannot say that either part of the transaction predominated over the other.").

${ }^{92}$ See, e.g., Seely v. White Motor Co., 63 Cal. 2d 9, 403 P.2d 145, 45 Cal. Rptr. 17 (1965). 
ration and opportunism, ${ }^{93}$ the current standard for service transactions is less protective than that ordinarily applied to the sale of goods. This discrepancy demands a careful investigation of the relevant cases to learn the reasons given for this difference in treatment and to discern the judiciary's sensitivity to the considerations advanced in this Comment.

Many of the cases in which courts have been asked to reconsider the legal rules for service transactions reveal little except a judicial propensity to state sweeping and familiar legal conclusions with scant regard for underlying motivations and policies. Courts very often begin and end their consideration of the problem with a few blunt comments, such as: "We regard it as the better part of wisdom not to extend as a matter of law implied warranties from sales to service contracts." 94 Accordingly, "[w]e will just stay with that reliable fellow-the reasonably prudent man."95

To a significant extent this cursory treatment of the problem is based on two simple propositions: (1) implied warranties and strict liability apply to the sale of goods-referred to simply as sales, and (2) service transactions are just not sales. ${ }^{96}$ Reliance on this sale-service distinction has impeded efforts to resolve

${ }^{93}$ Although blanket comparisons are difficult, services have been seen above to pose several special problems for consumers-uncertainty, complexity, individual production, no chance for inspection-so that the possibility looms large that fewer services than goods are in either of the benign market categories (nonimpacted or rich experiences).

${ }^{94}$ Samuelson v. Chutich, 185 Colo. 155, 158, 529 P.2d 631, 633 (1974) (en banc) (emphasis in original).

${ }^{95}$ Id. at 159,529 P.2d at 634 . Similarly, another court stated: "An engineer, or any other so-called professional, does not 'warrant' his service or the tangible evidence of his skill to be 'merchantable' or 'fit for an intended use.' These are terms uniquely applicable to goods." Audlane Lumber \& Builders Supply, Inc. v. D.E. Britt Associates, Inc., 168 So. 2d 333, 335 (Fla. Dist. Ct. App. 1964), cert. denied, 173 So. 2d 146 (Fla. 1965). A few key citations are normally added, but no fresh analysis is regarded as necessary because, as an Idaho court recently explained in denying the applicability of strict liability to repair services: "Almost uniformly any such extension of the rule has been consistently and expressly rejected." Hoffman v. Simplot Aviation, Inc., 97 Idaho $32, \ldots, 539$ P.2d 584, 587 (1975). "The rationale has been thoroughly explored in the authorities and commentators set forth above and reiteration herein would serve no purpose." Id. at —, 539 P.2d at 588. Although that court actually did provide a glimpse of its reasons for denial of strict liability, the casual attitude toward the need to explore carefully the issues and competing policies mirrors much of the case law in the area.

${ }^{96}$ Recent commentary has criticized extensively the sale-service dichotomy and argued for its abandonment, particularly in the area of strict tort liability, on historical, economic, and policy grounds. See, e.g., Comment, Sale-Service Hybrid Transactions: A Policy Approach, 28 Sw. L.J. 575 (1974); Comment, Continuing the Common Law Response to the New Industrial State: The Extension of Enterprise Liability to Consumer Services, 22 U.C.L.A.L. REv. 401 (1974). 
appropriately hybrid cases involving both sale and service aspects by encouraging the judiciary to categorize factual situations mechanically. The tendency is readily observable in cases dealing with hospitals' and blood banks' liability to patients contracting hepatitis as a result of transfusions of infected blood. ${ }^{97}$ Recognizing, then, that many courts deal with service cases in a. most superficial and unsatisfactory manner, ${ }^{98}$ this Comment looks past this mass of cases to a few outstanding examples of those less frequent cases in which courts grapple with some of the basic issues. These courts' conclusions-either finding valid reasons to deny extending implied guarantees to service transactions or suggesting that some service providers be subject to a stricter standard than the traditional negligence rulewill be explored, and the framework presented here will be applied to determine if it could have helped the courts deal with the difficult questions they faced.

${ }^{97}$ Jurisdictions vary in their responses to the question whether a blood transfusion constitutes a "sale" of blood by the supplier hospital. Compare Perlmutter v. Beth David Hosp., 308 N.Y. 100, 123 N.E.2d 792 (1954), with Cunningham v. MacNeal Memorial Hosp., 47 Ill. 2d 443, 266 N.E.2d 897 (1970).

${ }_{98}$ The judicial caution in applying warranty and strict liability concepts to service cases, presumably based on the "products" wording of the Restatement (Second) of Torts and the Uniform Commercial Code's exclusive application of implied warranties to the sale of goods, is particularly anamolous when viewed in light of the frequent examples of past judicial activism in this general area of law. This "failure of nerve" in the service area has been rejected by leading commentators who consistently stress the past trend of activism and the continuing need to view statutory frameworks not as boundary lines, but as invitations to apply similar legal rules to analogous situations outside the statute's limits. See, e.g., Farnsworth, Implied Warranties of Quality in Non-Sales Cases, 57 Colum. L. Rev. 653 (1957); Murray, Under the Spreading Analogy of Article 2 of the Uniform Commercial Code, 39 Fordham L. Rev. 447 (1971).

In one sense, the entire development of strict liability can be viewed as a judicial refusal to be bound by the statutory "intricacies" of the "law of sales." This was the view of Justice Traynor in his path breaking opinion in Greenman v. Yuba Power Prods., Inc., 59 Cal. 2d 57, 64, 377 P.2d 897, 901, 27 Cal. Rptr. 697, 701 (1963), and the concept of a more flexible set of legal rules for consumer transactions was repeatedly stressed in the early strict liability decisions. See, e.g., Suvada v. White Motor Co., 32 Ill. 2d 612, 210 N.E.2d 182 (1965). Many courts have taken advantage of opportunities to extend the implied warranties statutorily provided for goods by the state codifications of the Uniform Commercial Code to areas outside the purview of Article 2, such as the sale of new housing and the leasing of goods. See, e.g., Bachner v. Pearson, 479 P.2d 319 (Alas. 1970); W.E. Johnson Equip. Co. v. United Airlines, Inc., 238 So. 2d 98 (Fla. 1970); Schipper v. Levitt \& Sons, Inc., 44 N.J. 70, 207 A.2d 314 (1965).

Such past departures required careful analysis of the rationale for these implied guarantees and a willingness to expand upon narrow precedents and legislative mandates, neither of which are possible within the confines of a rigid adherence to the sale-service distinction. As the Pennsylvania Supreme Court insisted in refusing to follow a lower court's summary dismissal of a service-based warranty claim, such decisions should not be made "without sufficient inquiry as to whether the policies for which warranties are implied in law would be furthered by their implication in this situation." Hoffman v. Misericordia Hosp., 439 Pa. 501, 508, 267 A.2d 867, 871 (1970). 


\section{B. Gagne-Unresolved Contradictions in an Important Precedent}

Gagne v. Bertran ${ }^{99}$ is perhaps the best known case recognizing that implied warranties are not necessarily limited to the sale of goods but nonetheless arriving at the conclusion that service providers should not be held to more than the usual negligence rule. In Gagne, the plaintiff hired a soil tester to measure the fill depth of a possible construction site. Informed that the tests showed the fill to extend only about one foot below the surface, the plaintiff proceeded to buy the lots, only to learn after construction on the property had begun that the fill actually went as deep as three to six feet. After incurring substantial unanticipated construction costs, he sued the soil tester under theories of negligence, deceit, and breach of implied warranty. Justice Traynor's basic response, perhaps cited and quoted as frequently as any statement by a court denying implied warranty claims in service cases, ${ }^{100}$ appears in his discussion of the plaintiff's negligence claim:

The services of experts are sought because of their special skill. They have a duty to exercise the ordinary skill and competence of members of their profession, and a failure to discharge that duty will subject them to liability for negligence. Those who hire such persons are not justified in expecting infallibility, but can expect only reasonable care and competence. They purchase service, not insurance. ${ }^{101}$

Earlier, in specifically rejecting the implied warranty claim, Justice Traynor concluded that "[t]he general rule is applicable that those who sell their services for the guidance of others in their economic, financial, and personal affairs are not liable in the absence of negligence or intentional misconduct." ${ }^{102}$ Thus two superficial incongruities are immediately manifest: (1) the denial of an implied warranty is based on the application of a general rule covering only those services relating to expert guidance and advice (presumably exempting stock brokers from liability, but not auto mechanics), and (2) the words so commonly quoted in rejecting implied warranties ${ }^{103}$ actually uphold an action for negligence.

9943 Cal. 2d 481, 275 P.2d 15 (1954).

${ }^{100}$ See, e.g., Hoffman v. Simplot Aviation, Inc., 97 Idaho 32, 539 P.2d 584, 589 (1975).

${ }^{101}$ Id. at 489,275 P.2d at 21.

${ }^{102} I d$. at 487,275 P.2d at 20.

${ }^{103}$ See notes $100-01$ supra \& accompanying text. 
Other substantive contradictions haunt the opinion. In ostensibly rejecting the breach of warranty claim, Justice Traynor spoke primarily of express warranties, concluding that "there was no express warranty agreement, and there is nothing in the evidence to indicate that defendant assumed responsibility for the accuracy of his statements."104 Nevertheless, in accepting the plaintiff's deceit theory, Justice Traynor emphasized that the defendant stated an opinion concerning fill depth that he could not reasonably have believed and upon which he knew the plaintiff would justifiably rely. ${ }^{105}$ If the statement of an opinion by the service provider induces "justifiable reliance" by the customer-the court acknowledged that the soil tester made no special promises about the accuracy of his reportsthen for all practical purposes the court implied a warranty within the soil tester's report and found the defendant liable because he failed to make appropriate disclaimers. Similarly, in his discussion of the evidence supporting the negligence claim, Justice Traynor declared the persuasive indicators of negligence to be the testimony of the defendant's employee who assisted in the fill test and observed fill at a four to five foot depth and "the testimony of the persons who dug the foundation trenches."106 The trenchdiggers would have been competent to testify only to the actual fill depth, not to the methods used by the soil tester; the court, therefore, apparently regarded testimony indicating that the soil tester's results were erroneous as persuasive evidence of negligence. Emphasis on result, however, is more appropriate to an implied warranty analysis than to a negligence claim. Thus both the deceit and the negligence arguments accepted by the court contain strong elements of an implied warranty theory despite the court's insistence that it rejected the applicability of the implied warranty claim. ${ }^{107}$

The analytic framework suggested here could have helped the Gagne court avoid or at least recognize many of these inconsistencies. The court indirectly gave positive responses to the three suggested preliminary questions ${ }^{108}$ it mentioned.

${ }^{104} 43$ Cal. $2 d$ at 487,275 P.2d at 20.

${ }^{105}$ Id. at $488,275 \mathrm{P} .2 \mathrm{~d}$ at 20 .

${ }^{106} \mathrm{Id}$. at $490,275 \mathrm{P} .2 \mathrm{~d}$ at 21 .

${ }^{107} I d$. at 487,275 P.2d at 20 . The final twist in this remarkable opinion is the court's determination that, despite being entitled to recover on both negligence and deceit grounds, the plaintiffs had thus far not shown any damages. Id. at 492, 275 P.2d at 23. For a discussion of this aspect of the case, see 43 CaLIF. L. Rev. 356 (1955).

${ }^{108}$ See notes 74-76 supra \& accompanying text. 
First, the transaction was described as one characterized by information impactedness: "Defendant held himself out as an expert, plaintiffs hired him to supply information concerning matters of which they were ignorant ...."109 Soil testing services apparently can be critically evaluated after purchase. Therefore, the information impactedness problems arising in this market are probably most like those in "limited experiences" markets, ${ }^{110}$ suggesting a combination of opportunism and deterioration. Second, the court's references to the more complex and presumably more accurate soil tests performed by soil engineers and geologists indicated that a range of techniques are available for performing this service. ${ }^{111}$ Third, on the question of profit-maximizing, the court implied that at least some service providers would try to take advantage of their inside information, noting that this defendant, fully cognizant of the unsatisfactory manner of his testing, when reporting the results "did not give his statement in the form of an opinion but as a representation of fact." 112 The court did not consider the question of the presence of other possible forces to curb deterioration or opportunism, but the opinion's failure to mention special licensing rules, work regulations, or professional codes for soil testers allows us to assume their absence and insert our own affirmative answer to that final preliminary inquiry.

The positive responses to the preliminary inquiries indicate that the basic assumptions underlying the predictions of market outcomes and the explanation of the role of legally implied guarantees fit the particular case, and the considerations identified earlier to guide the choice of a legal rule ${ }^{113}$ can and should be applied. In deciding whether an effort-oriented neg-

10943 Cal. $2 \mathrm{~d}$ at 489,275 P.2d at 21.

110 Consumers can judge the accuracy of soil test reports when the land is put to some use that requires extensive digging and the true fill depth is revealed. Although contractors and some others may regularly require such services, plaintiff apparently previously purchased this type of service only four times in a three year period, and not at all in the last five years. Id. at $484,275 \mathrm{P} .2 \mathrm{~d}$ at 18 . Presumably some customers in this market make more regular use of soil tests, so that the problems here are less severe than in pure limited experiences market. This case also demonstrates key aspects of cue-reliant buying because of the indications that this buyer chose this soil tester on the basis of a brief string of favorable past experiences that led him to overestimate the true quality of this tester's work. Id. The case exemplifies the difficulties inherent in attempting to pigeonhole an entire service market into one of the four categories developed above. Subdivision of consumers into groups often will be necessary to enable estimation of the net effect that the diverse forces generated by the groups have upon the full market.

iII Id. at 490,275 P.2d at 21 .

${ }^{112} I d$. at 489,275 P.2d at 21 .

${ }^{113}$ See text accompanying notes 77-78 supra. 
ligence rule or an outcome-oriented implied warranty rule would be the more appropriate law of implied guarantee for the soil testing market, the crucial concerns stressed-the impact on opportunism and deterioration, the transaction costs of enforcement, the possible incentives to inefficiency, the implied boundary line on allowable risks, and the justness of the outcome-provide a relatively stable basis for decision. Outcome-oriented rules are superior in curbing the type of opportunism operative in Gagne, where the soil tester failed to disclose the flimsiness of his procedures and findings and subsequently represented himself as a fully qualified expert. The enforcement obstacles to the consumer are necessarily higher under a negligence rule than under an implied warranty, simply because a plaintiff must prove more. Consequently, in many cases, including the instant one, only fortuitous events such as the availability of the participating employee's testimony ${ }^{114}$ enable consumer plaintiffs to vault those obstacles. Neither rule threatens to produce major inefficiencies on either the producer or consumer side. On the one hand, soil testers would not adopt unnecessarily complex procedures merely to meet an effortrelated standard of care; on the consumer side, the unavailability of information mitigates the concern that application of a liability rule would discourage consumers from utilizing selfprotective measures.

The court's refusal to deviate from the traditional negligence rule appears related to its deep but misdirected concern for the remaining two components, individual justice and the boundary of allowable risks. Justice Traynor espoused a "general rule" of no liability absent negligence for those contributing "guidance of others in their economic, financial, and personal affairs ...."115 This rule, compelled by the presumption against the expectation of "infallibility,"116 constitutes an important element of our social concept of individual justice in the marketplace. But although this expression of social concern is perhaps apposite to psychologists, investment brokers, ministers, and other advice givers, the rule hardly fits a soil tester who reports on an objectively measurable factual matter. Thus, an appropriate consideration of marketplace justice was employed in an inappropriate context; the desire to shield a sincere psychologist whose best recommendations fail to solve a

\footnotetext{
${ }^{114} I d$. at 490,275 P.2d at 21 .

115 Id. at 487,275 P. $2 \mathrm{~d}$ at 20.

${ }^{116}$ Id. at 489,275 P.2d at 21.
} 
patient's problems should not extend to a soil tester who provides inaccurate reports.

Secondly, the court's conclusion that the low price paid indicates the lack of any guarantee suggests that a low price purchases only a report devoid of promises. Apparently, this low-cost, no assurance alternative is within the boundaries of the marketplace risks that consumers should be allowed to bear. An outcome-oriented rule containing a merchantability standard would have enabled the court to maintain this attitude without rejecting the implied warranty theory. In fact, the threat of additional successful negligence claims against low-cost operators such as the Gagne soil tester poses a greater danger of driving this "desirable" option off the market than does a carefully enforced merchantability rule that places heavy stress on the price signal. ${ }^{117}$

The proposed inquiries would not save the Gagne court from ultimately having to resolve certain fundamental tensions in the opinion, particularly the dichotomy between faulting the soil tester for pretending to be an expert and recoiling from imposition of full liability because of the belief that the low price should have warned the customer that no guarantees were included. On balance, however, an implied warranty approach emerges as the preferred alternative to a traditional negligence rule because of its reduced enforcement obstacles and greater sensitivity to opportunism. Through careful application of the concepts of merchantability and consequential damages, an implied warranty rule also offers a more acceptable definition of the boundaries of allowable marketplace risks by providing the flexibility required to ease the opinion's basic tensions. If the strength of the low price signal were deemed great, and if such inexpensive, if not fully reliable, soil testing services were found to be desirable marketplace risks, the implied warranty theory could be upheld even while recovery was denied, on the ground that the service received was merchantable for the price paid. On the other hand, if some relief were desirable in order to limit the availability of such unreliable work and protect the consumer who "justifiably relied" on the service provider, the service could be found unmerchantable, but recovery restrained by the reasoning relied on in Gagne-the real injury proximately

117 Under the court's analysis, if a significant percentage of reports were erroneous, practically all services performed by these nongeologists would be classified as negligent, regardless of the low price, thereby posing a substantial threat to their continued presence on the market. 
caused by the breach was the difference between the value of the land calculated with its true fill depth known and the price actually paid. ${ }^{118}$ The increased construction costs could then be regarded as consequential damages too remote to be recoverable. In any event, with the aid of these inquiries, the inconsistent arguments that plague the opinion could have been avoided. These inconsistencies caused the unnecessary rejection of an implied warranty rule, despite clear advantages of the rule in this type of service market.

\section{Broyles-Uncertainty as a Faulty Boundary on Implied Warranties}

Broyles v. Brown Engineering Co. ${ }^{119}$ represents another example of a court grappling with the question of the guarantee standard to be applied to a service market. In a case involving the hiring of an incorporated group of civil engineers to provide plans for a drainage system, the court this time applied an implied warranty rule.

Immediately noteworthy is the court's traditional and understated approach, which produces a potentially sweeping holding in the terms of conventional contract analysis: "An action for breach of duty arising out of a contract of employment, express or implied, to accomplish a particular result, is based on failure to perform the special agreement regardless of negligence." 120 With this one brief comment and a few cites to other jurisdictions, the opinion quickly encompasses a vast range of service transactions. Hiring someone to fix a broken refrigerator, move one's belongings, repair a carburetor, or mow a lawn, nestles comfortably into the general category "of employment to accomplish a particular result."

From this starting point, the court's key to finding the engineers liable for the failure of their plans was to establish the existence of an implied contract to successfully achieve a particular result, because no explicit guarantee existed. Once again the court turned to traditional contract concepts, asserting: "An implied contract arises where there are circumstances which, according to the ordinary course of dealing and common understanding, show a mutual intent to contract."121 Noting that the engineers represented themselves as experts and that

\footnotetext{
11843 Cal. 2d at 490-92, 275 P.2d at 21-23.

119275 Ala. 35, 151 So. 2d 767 (1963) (per curiam).

${ }^{120} \mathrm{Id}$. at 38,151 So. $2 \mathrm{~d}$ at 770 .

${ }^{121} \mathrm{Id}$.
} 
all parties understood the functional requisites of the drainage system, the court concluded:

[A]s we view all the circumstances and the nature of the contract, .. . the parties mutually intended an agreement of guaranty as to the sufficiency and adequacy of the plans and specifications to accomplish proper and adequate drainage. To hold otherwise would be to ignore practical and common sense implications that arise from contractual dealings and negotiations as here presented in the complaint. ${ }^{122}$

The only distinguishing features of the "dealings and negotiations as here presented" were the alleged expertness of the service, the customer's express need for the attainment of a specific result, and the service provider's acceptance of the job with an awareness of that need, but without making any explicit promise to achieve the particular result. These features, however, may characterize numerous other service transactions. Thus, the court's superficially unstartling, traditionally worded analysis arrived at a conclusion that on its face makes many, if not most, service transactions subject to an implied warranty standard, rather than to the familiar negligence rule. ${ }^{123}$

In determining the applicability of an implied warranty rule, the Broyles court analyzed few of the suggested relevant market considerations. The court did refer to one of the essential elements of an information impacted situation, noting that "defendant professed to be expert or held himself out to be ...."124 The court also indicated that an implied warranty rule possesses advantages over the negligence standard both because of reduced enforcement obstacles ${ }^{125}$ and because of greater marketplace justice. ${ }^{126}$ Nonetheless, the tone of the opinion and its stress on mutuality of intent are basically at odds with the approach advocated here. Broyles fails to concentrate on the market impact of different legal rules and make a con-

${ }^{122} I d$. at 38,151 So. $2 \mathrm{~d}$ at 771 .

${ }^{123}$ The Broyles decision has yet to serve as a growth point in the law, despite its apparent potential for such a role. See Note, Implied Warranties in Service Contracts, 39 Notre Dame Law. 680 (1964). Hoffman v. Simplot Aviation, Inc., 97 Idaho 32, 539 P.2d 584 (1975) is typical of recent cases explicitly refusing to follow Broyles.

124275 Ala. at 38, 151 So. $2 d$ at 771 .

${ }^{125} I d$. at 40,151 So. $2 \mathrm{~d}$ at 772 ("Such allegations [of negligence] cast on him a difficult burden of proof.").

${ }^{126} I d$. ("Resistance as here to accountability does not dissipate the fairness and justice of such an implication."). 
scious and openly expressed choice between such rules based primarily upon their respective impacts. ${ }^{127}$

This deficiency comes into sharp focus in the later sections of the opinion where the court attempted to circumscribe the applicability of its holding. No effort was made to define more precisely the key phrase, "contractual dealings and negotiations as here presented," in terms of more ordinary services than those provided by civil engineers. The opinion does, however, note: "We recognize that in the absence of an express contract, the courts are reluctant to construe contractual dealings and services of lawyers, physicians and architects, and probably some other professions, as implying a contract of guaranty or insurance of favorable results."128 The court further explained that in construing the warranty accompanying other services, "[i]t all depends on the nature of the employment and the particular services rendered," especially the extent to which elements beyond the control of the service provider temper the outcome. ${ }^{129}$ Thus, the traditional negligence rule should be retained if external forces substantially affect the eventual result.

To evaluate its persuasiveness and reach, the Broyles opinion must be examined in light of the theories and model suggested by this Comment. Although the existence of production uncertainties is definitely one element to be weighed, this criterion alone cannot determine adequately the proper reach of the implied warranty doctrine. The basic weakness of the uncertainty standard is demonstrated through consideration of the proposed preliminary concerns-information impactedness, range of techniques, profit-maximizing behavior, and curbs on deterioration and opportunism. ${ }^{130}$ Although the Broyles court apparently perceived the applicability of the first inquiry-virtually all complex service markets are characterized

${ }^{127}$ But see Note, Extension of Warranty Concept to Service-Sales Contracts, 31 IND. L.J. 367 (1956). That commentator stresses that "the expectations of the parties must be considered. . . . It follows that implied warranties should apply to service contracts only when a specific result can reasonably be expected and is a basis of the bargain." Id. 375 (emphasis supplied). This statement, following on the heels of an assertion that clients do not expect their lawyers to win, but merely to try hard, exemplifies the contrast with the argument set forth in this analysis. Instead of using the concept of "reasonable expectations" to tell consumers that the law may not recognize the validity of what they in fact believe, the suggested focus here is on the actual expectations of consumers, the role of sellers in manipulating and responding to those expectations, and the marketplace impact of such attitudes and behavior.

128275 Ala. at 38,151 So. $2 d$ at 771 .

${ }^{129} \mathrm{Id}$.

${ }^{130}$ See text accompanying notes 74-76 supra. 
by one or more of the described varieties of information impactedness - the court neglected to consider whether the service providers have available a range of techniques possessing varying success probabilities. Instead, the opinion asks if the probability of success is substantially less than 100 percent. ${ }^{131}$ This question is inadequate because even providers of intensely complex professional services have access to a range of techniques. Law firms may be able to alter considerably the probability of prevailing in a certain case by their assignment of particular attorneys to conduct the litigation, their willingness to incur costs in preparation for trial, and their reduction of outside responsibilities for the attorneys litigating the case. Similarly, doctors regularly choose between different techniques in recommending further tests or preliminary treatment for their patients. They do not routinely admit every patient who complains of shortness of breath to the hospital for an exhaustive battery of tests to check for every possible condition relating to this symptom, although to do so would theoretically increase the probability of appropriate treatment. Therefore, courts must recognize that despite the substantial degree of result uncertainty connected with providing very complex services, skilled professionals can affect significantly the probability of success. Stricter implied guarantees might motivate the choice of more desirable techniques. Accordingly, the Broyles observation that some service providers face substantial performance uncertainties is analytically insufficient to preclude automatically the use of implied warranties in service markets. ${ }^{132}$

Having affirmatively answered this second preliminary inquiry by observing that skilled professionals possess a range of techniques, the court should have analyzed the third and fourth components-profit-maximizing by service providers due to their inside information, and existence of forces within the market to curb deterioration and opportunism. Instead,

${ }^{131}$ That is essentially the meaning of the court's statements concerning services in which the outcome "depends on factors beyond the control of the practitioner" and the whole enterprise is "to a great degree experimental." 275 Ala. at 38-39, 151 So. $2 \mathrm{~d}$ at 771. This same inquiry has been effectively precluded in goods markets because the basic expression of strict liability for manufacturers specifies that a seller will be held liable even though he "has exercised all possible care in the preparation and sale of his product." Restatement (SECOND) of ToRTs $\$ 402 \mathrm{~A}(2)$ (a), at 348 (1965). Thus, production uncertainties cannot shield providers of goods from liability.

${ }^{132}$ The ability of legally implied guarantees to motivate the choice of different techniques is as relevant here as it was in the above analysis, regardless of the presence of greater production uncertainties. There is no logical reason why such uncertainties, standing alone, should compel us to leave the choice of techniques to the unmodified behavior of sellers in markets that are still characterized by information impactedness. 
Broyles asserts that when production is uncertain, common sense and dealing suggest that no guarantees are implied. The court's confusion ensues from its exclusive consideration of examples of professional services, although surely these are not the only types of services marked by substantial production uncertainties. Prevalent notions of true professionalism suggest that profit-maximizing does not occur and curbs on opportunism and deterioration may be unnecessary. ${ }^{133}$ Thus, many of the proffered market deterioration and opportunism predictions may not be applicable to true professions. Society perceives that well-trained professionals "do the best they can," largely because of professional ethical codes, entrance requirements, and socialization mechanisms. These critical forces may check much of the deterioration and opportunism that strike more wholly commercial markets. One expects professionals to carefully weigh costs and benefits, but primarily as a type of agent for the client/patient, and not to take advantage of his trust.

The predominantly negative responses to the preliminary inquiries indicate that the implied guarantee rule does not serve quite the same functions in markets dominated by "serviceprofessionalism ideals" that it does in more commercial settings. The key implication is not that professionals would fail to alter their behavior if the standard were changed, but rather that stricter liability standards are unlikely to coax professional service providers who adhere to the ideals of their profession into utilizing more careful production techniques. ${ }^{134}$ Imposition of liability for an unisuccessful result under a legal guarantee rule may effectuate certain behavioral modifications, such as inducing practitioners to adopt defensive medicine techniques and abandon high risk activities, but these alterations do not necessarily signify a higher quality of care.

In terms of the other suggested considerations for evaluating the relative merits of different legal standards, the use of

${ }^{133}$ Professionals might well be calculating and even profit oriented in matters of where to practice, what specialty to enter, and other similar considerations. Such behavior would not, however, characterize decisions pertaining to the appropriate level of care in performing their particular service for any individual customers. For a clear statement of the "service ideal" as the defining characteristic of true professions, see Wilensky, The Professionalization of Everyone?, in THE Sociology of Organizations: Basic STudies (O. Grusky \& G. Miller eds. 1970).

${ }^{134}$ Although the discussion points generally in the opposite direction, there may be other compelling reasons to opt for stricter liability standards. The recognition that one is unlikely to motivate improved techniques surely does not terminate the quest for the optimal legal standard of implied guarantee for such a market. Rather, its effect is to remove one key element, the likelihood of creating incentives that will lead to technique upgrading, from the balance that otherwise favors the outcome-related type of rule. 
outcome-oriented rules in professional markets can obviate some of the producer and consumer inefficiencies of effortoriented negligence rules, ${ }^{135}$ but only at the cost of what may be a wholly inappropriate definition of the boundary of allowable risk. Society is not likely to want surgeons to refuse to operate simply because there is only a slim chance the patient will recover. The use of such outcome-oriented rules may also pose a fairly major affront to society's sense of marketplace justice ${ }^{136}$ by imposing liability on highly skilled persons who have done their best to successfully complete tasks posing enormous challenges and defying favorable resolution on a regular basis.

Thus the Broyles court may have stumbled onto a proper distinction between professional and non-professional markets, although mistakenly expressing the difference in terms of mere production uncertainties. Two critical caveats need to be emphasized at this point. First, some groups seeking to label themselves professions may not adhere to the "service ideal" to an extent warranting this advanced analysis, even if perceived to do so by sizable segments of the populace. ${ }^{137}$ Courts may feel that such service providers generally take advantage of their special information and that ethical codes and minimum certification requirements fail to effectively counteract opportunism and deterioration. In that case, the potential of legally implied guarantees to combat these problems must be added to the equation in order to determine if a shift to a stricter, outcomeoriented rule might not indeed offer advantages. ${ }^{138}$ Second, the choice of the familiar negligence rule does not imply that professional service providers will never be found liable. The negligence rule is a sort of litmus test of adherence to the service ideal. If one provides services in a manner measuring up to the standard of acceptable practice in the profession, then no liability will follow upon unfavorable results. Deviations from that standard, however, will occasion liability if the desired results are not produced.

Thus, an effort-oriented rule may be particularly appropriate for a truly "service ideal" type market, so long as the stan-

${ }^{135}$ See notes 65-68 supra \& accompanying text.

${ }^{136}$ See notes 72-73 supra \& accompanying text.

${ }^{137}$ For an indication that numerous members of the medical profession, which surely is regarded as adhering to the "service ideal," often are failing to merit the designation, see U.S. News \& World ReP., Sept. 13, 1976, at 55.

${ }^{138}$ The assumption that choice of techniques decisions are made on a profitoriented basis would once again be the starting point of the analysis, despite the service providers' claim that they are guided by the "service ideal." 
dard employed does not include superfluous elements encompassed by "defensive practice." One cannot, however, properly define the services requiring such different rules by sole reliance on the Broyles court uncertainty criterion. Rather, one must carefully examine both the enumerated preliminary inquiries and balancing considerations to make appropriately these difficult distinctions.

\section{Newmark-Long Step Toward Useful Analysis}

Beginning with a resounding rejection of the sale-service distinction as a basis for decision, Newmark $v$. Gimbel's, Inc. ${ }^{139}$ perhaps comes closest to the analysis urged here. The trial court dismissed the warranty claim of Mrs. Newmark, whose hair and scalp were severely burned after a cold wave was applied by a beauty parlor operator, because her transaction with the beauty parlor was not a sale under New Jersey's version of the Uniform Commercial Code. The New Jersey Supreme Court flatly rejected that nonanalysis: "Having in mind the nature of a permanent wave operation, we find that the distinction between a sale and the rendition of services is a highly artificial one."140

After labeling the transaction "a hybrid partaking of ingredients of a sale and a service,"141 the court appropriately commenced answering several relevant inquiries by recognizing that the situation would necessarily produce one or more of the described varieties of information impactedness:

A beauty parlor operator in soliciting patronage assures the public that he or she possesses adequate knowledge and skill .... When a patron responds to the solicitation she does so confident that any product used in the shop has come from a reliable origin and can be trusted not to injure her. She places herself in the hands of the operator relying upon his or her expertise both in the selection of the products to be used on her and in the method of using them. . . [ [T]he patron is a mere passive recipient. ${ }^{142}$

The most likely source of information impactedness problems in the beauty parlor service market is significant cue reliance, causing a confounding of before and after the fact evaluation. Therefore, one would expect to witness the limited deteriora-

\footnotetext{
13954 N.J. 585,258 A.2d 697 (1969).

140 $I d$. at $592,258 \mathrm{~A} .2 \mathrm{~d}$ at 700 .

${ }^{141}$ Id. at $593,258 \mathrm{~A} .2 \mathrm{~d}$ at 701 .

${ }^{142} I d$. at 593-94, $258 \mathrm{~A} .2 \mathrm{~d}$ at 701 .
} 
tion and substantial opportunism characterizing cue-reliant markets. ${ }^{143}$

The quoted discussion of operator expertise, the court's earlier comments concerning the labelling on the wave solution, and the questions the operator chose to consider, combine to suggest that the court implicitly gave an affirmative response to the second preliminary inquiry, the availability of a range of alternate techniques. The court concluded that there are indeed a variety of techniques used by beauty parlors that may have an impact upon the customer's ultimate satisfaction and health. Newmark also manifests concern for the third preliminary inquiry, profit-maximizing behavior by service providers. The court, noting that businesses generally operate to make money, suggested that such operation may occasionally entail utilization of superior information for personal profit. The clues to this attitude appear later in the opinion where the court discussed the differences between a "commercial enterprise" and a profession, stressing that a commercial enterprise solicits customers and "caters publicly not to a need but to a form of aesthetic convenience or luxury ...."144 The New Jersey Supreme Court did not examine the fourth preliminary inquiry, whether existing forces could inhibit opportunism and deterioration in the specific service market-in this case, beauty parlors. Generally, however, it appears that although beauticians are now licensed in many states, presumably placing some minimal floor on the skill and care that they possess, such inhibiting forces are absent in the market.

The court summarized much of its detailed weighing of the best rule for this market by noting that implied warranties were never intended to be limited by the reach of Article 2 of the Uniform Commercial Code, that such concepts had already been extended to leasing and mass-produced new housing, and that "the policy reasons for imposing warranty liability in the case of ordinary sales are equally applicable to a commercial transaction such as that existing in this case ...."145 In the terms stressed here, the court invoked explicitly the concept of individual marketplace justice ${ }^{146}$ and recognized that substantial

${ }^{143}$ See text accompanying note 27 supra.

${ }^{144} 54$ N.J. at $596,258 \mathrm{~A} .2 \mathrm{~d}$ at 702.

${ }^{145} \mathrm{Id}$. at $594-95,258 \mathrm{~A} .2 \mathrm{~d}$ at $701-02$.

${ }^{146} I d$. at 592-93, 258 A.2d at 700 ("[D]efendants argue that if, in addition to recommending the use of a lotion or other product ... they applied it, such fact (the application) would have the effect of lessening their liability to the patron by eliminating warranty.... There is no just reason why it should."). 
transaction costs of enforcement favor some type of outcomeoriented rule. ${ }^{147}$ Certainly the basic policy reasons that the court initially articulated for imposing implied warranties must include some notion of the permissible extent of marketplace risks. ${ }^{148}$ One may assume, therefore, that the court believed that cold waves causing injuries to innocent customers are outside the proper boundary of allowable risks and consequently subject to liability for resultant harm.

Although stating the inquiries in somewhat different fashion, the Newmark court can be credited with having raised or hinted at most of the considerations stressed by this Comment as relevant to the choice of a legally implied guarantee. Newmark also makes an attempt, reminiscent of that made in Broyles, to define the outer boundaries of the new rule it proposes for hybrid transactions. The court felt particularly compelled to make this effort because of defendant's claim that the situation was indistinguishable from Magrine $v$. Krasnica,${ }^{149}$ in which the same court refused to hold a dentist liable when a hypodermic needle broke off in a patient's jaw during an attempted injection of a local anaesthetic. Both cases involved defective products apparently causing injury to consumers in the course of the performance of a service. Newmark outlines many bases for distinguishing beauticians from dentists and doctors, most derived from the central difference discussed above between a "commercial enterprise" and a "profession." The court pointed out that medical professionals, who cannot advertise, provide services only upon the perceived need of the patient, exercise their best judgment in difficult diagnostic problems, and perform tasks that are not mechanical or routine. ${ }^{150}$ In summarizing its attitude toward increased warranty liability for medical service providers, the court concluded:

Neither medicine nor dentistry is an exact science; there is no implied warranty of cure or relief. There is no representation of infallibility and such professional men should not be held to such a degree of perfec-

${ }^{147} I d$. at $595,258 \mathrm{~A} .2 \mathrm{~d}$ at 702 (" $[\mathrm{P}]$ ractical administration suggests that the principle of liability be expressed in terms of strict liability in tort thus enabling it to be applied in practice unconfined by the narrow conceptualism associated with the technical niceties of sales and implied warranties.").

${ }^{148}$ See notes 69-71 supra \& accompanying text.

${ }^{1 * 9} 94$ N.J. Super. 228, 227 A.2d 539 (Hudson County Ct. 1967), aff'd sub nom. Magrine v. Spector, 100 N.J. Super. 223, 241 A.2d 637 (App. Div. 1968), aff'd, 53 N.J. 259, 250 A.2d 129 (1969).

${ }^{150} 54$ N.J. at 596,258 A.2d at $702-03$. 
tion. . . . Practitioners of such callings ... must be deemed to have a special and essential role in our society ... . In our judgment, the nature of the services, the utility of and the need for them, involving as they do, the health and even survival of many people, are so important to the general welfare as to outweigh in the policy scale any need for the imposition on dentists and doctors of the rules of strict liability in tort. ${ }^{151}$

Thus Newmark goes well beyond Broyles' single-minded focus on the uncertainty principle, suggesting as a preliminary matter that professionals are inherently less exploitative than service providers in commercial enterprises, and recognizing that many professional tasks are marked by substantial uncertainties. Society regards the particular services provided by these medical professionals as so clearly within the range of desired marketplace alternatives that other policy considerations fail to justify imposing any additional burdens through stricter implied guarantees that might limit the availability of such services.

The Newmark court thus exceeded the Broyles court in its sensitivity to the relevant factors dictating rules for true professionals different from those applied to basic commercial service providers. Newmark also eschews the pitfall of announcing a single general criterion to provide the rule of decision for future cases requiring some limit on the broad use of strict liability concepts. The one Newmark step down an analytically empty path is scattered language suggesting an important distinction between "pure services" and hybrid cases in which consumers purchase both product and service. ${ }^{152}$ The court paused to reiterate that sale-like elements were involved: "Obviously in permanent wave operations the product is taken into consideration in fixing the price of the service." 153 Similarly, in reviewing Magrine, the court recalled approvingly that it found the dentist not subject to strict liability "because the essence of the relationship with his patient was the furnishing of professional skill and services. We accepted the view that a dentist's bill for services should be considered as representing pay for that alone."154

${ }^{151} \mathrm{Id}$. at 596-97, $258 \mathrm{~A} .2 \mathrm{~d}$ at $702-03$.

${ }^{152}$ Several of the commentators who analyzed Newmark at the time it was decided (the comments were written after the Appellate Division opinion which the Supreme Court here affirmed) also criticized this distinction between hybrids and so-called "pure services." See 34 Mo. L. Rev. 604, 611 (1969); 47 Tex. L. Rev. 716, 722-23 (1969). But see 71 W. VA. L. Rev. 213, 216-18 (1969).

${ }^{153} 54$ N.J. at $593,258 \mathrm{~A} .2 \mathrm{~d}$ at 701.

${ }^{154} \mathrm{Id}$. at $596,258 \mathrm{~A} .2 \mathrm{~d}$ at 702 . 
That the patient would not normally be viewed as "buying" the dentist's hypodermic needle was somehow important in determining which legal rule should govern the transaction. The Newmark court perceived this distinction to be of continuing vitality: when elaborating on the differences between beauticians and medical professionals, Justice Francis noted that beauty parlors offer "the rendition of non-professional services and the application of products for which a charge is made," 155 but that medical service providers "are not producers or sellers of property in any reasonably accepted sense of the term. In a primary sense they furnish services in the form of an opinion ...."156

Although the Newmark court cannot be faulted for limiting its holding to the sale-service hybrid transaction it faced, the suggestion that differentiating services in which a product is part of the package from those which are "pure service" should isolate situations meriting strict liability from those deserving negligence rules is perhaps the court's one major analytic error. After carefully sketching the more appropriate bases for decision in the rest of its opinion-the extent of the customer's reliance, the range of allowable and desired marketplace risks, the costs of enforcement-the Newmark court should not have resorted to artificial line drawing between pure services and hybrids. The unfortunate consequences of this reasoning may emerge subsequently when courts engage in such unrewarding activities as comparing the relative prices of the sale and service components to decide if the disputed transaction contains sufficient aspects of a sale to avoid classification as a pure service. ${ }^{157}$ Furthermore, the particular weaknesses of this distinction could be most glaring if cases present situations of so-called pure services that are not performed by licensed professionals, or that the court views as less socially essential than medical efforts. When circumstances require a court to announce a legal standard of implied guarantees for marriage counselors and janitorial services, the lines of inquiry herein urged but approximated only in part by the Newmark court would provide the clues necessary to uncover the most appropriate rule. Artificial line drawing inherent in the pure service concept should be jettisoned.

In addition to its other contributions, Newmark potentially

${ }^{155} I d$.

${ }^{156}$ Id. at 597,258 A.2d at 703.

${ }^{157}$ Cf. Carpenter v. Best's Apparel, Inc., 4 Wash. App. 439, 442-43, 481 P.2d 924, 926-27 (1971) (analogous weighing method employed in basic sale-service context). 
aids courts deciding which particular groups claiming to be professionals guided by the "service ideal" are properly deserving of that appellation ${ }^{158}$ in setting the legal standard for their service market. The court's stress on the current noncommercialization of medicine and dentistry suggests that as self-proclaimed professionals begin to advertise and take other steps to actively solicit customers rather than merely responding to a "felt need," they increasingly resemble commercial enterprises for which the standards of implied warranties are appropriate. Service providers engaging in sizable commercial activities can hardly claim that they are so far removed from a profit orientation in their dealings with individual clients and patients that the type of predictions generated by these models of information impacted markets are inapposite. This recognition of increasingly profit-motivated decisions in the choice of treatment or performance does not necessarily lead to imposing an implied warranty upon such markets. It could, however, tip the balance back by indicating that stricter, outcome-related rules could have a positive effect on curbing deterioration and opportunism because these "professional" service providers behave substantially like typical entrepreneurs in the management of their affairs and the choice of production and marketing strategies. ${ }^{159}$

\section{The Decisional Framework Revisited: Its Limits}

Two important final observations can be made about the probable outcome of employing the decisional framework suggested by this Comment. First, although this approach essentially involves market-by-market, case-by-case determination of legal rules, many of the cases involving everyday consumer services are likely to yield the same outcome. After answering the preliminary inquiries which are basically designed to warn of unusual circumstances, courts deciding these "normal cases" involving barbers, movers, gardeners, television repairmen, and comparable service providers, will proceed to the balancing considerations. Because outcome-related rules of the implied warranty type generally offer greater potential for combating opportunism and deterioration, less prohibitive transaction costs of enforcement, and markedly stronger in-

${ }^{158}$ See notes $129-33$ supra \& accompanying text.

159 This decision admittedly may be a very difficult one for the courts to make. If the group claiming that it merits treatment as a true profession is already subject to extensive legislative regulation, the courts may react cautiously to avoid altering suddenly the rules in a way likely to reshape fundamentally an important market. 
centives for efficient behavior on the producer side, the implied warranty rule will be favored typically for all these "normal service" markets if the courts apply this analytical framework. ${ }^{160}$ The real value of this admittedly elaborate decision process, therefore, is that in addition to heralding the proper extension of implied warranty concepts to many service transactions, it also provides a series of check points at which particular situations can be categorized as exceptional markets better served by maintaining the more familiar negligence rule.

Finally, the series of market descriptions and the assessment of the potential role of implied guarantee rules should give warning that the other probable result of utilizing this decisional framework will not be, unfortunately, the elimination of all information impactedness-related problems from service markets. Many particularly troublesome service markets, such as the auto repair and home improvement markets, are characterized by rampant opportunism, especially in the performance of unnecessary and unnecessarily costly work. ${ }^{161}$ No implied guarantee rule can effectively combat such opportunism, with the possible exception of the imposition of some type of drastic agency or fiduciary obligations on service providers, obligations that would be fundamentally at odds with the basic assumptions of our commercial system. ${ }^{162}$ In short, beyond helping judges arrive at better-reasoned decisions in cases requiring a new implied guarantee standard for particular markets, this analysis should alert policy makers to the necessary limits of such legal rules. Alternatives that do not necessarily involve litigation and the courts, such as licensing, disclosure rules, and official publication of comparative information, ${ }^{163}$ will have to be implemented along with appropriate implied guarantees to alleviate effectively the problems caused by information impactedness.

${ }^{160}$ Two possible new frontiers for the extension of implied warranties are the insurance and computer programming service markets. See Comment, Liability for Defects in Computer Software, 53 J. URB. L. 280 (1975) (computer programming); 9 AkroN L. REV. 584 (1976) (insurance).

${ }^{161}$ See note 2 supra \& accompanying text.

${ }^{162}$ Even the strictest fiduciary rules, such as making the service provider responsible for protecting the full range of his customer's interests, would not be very effective unless they somehow alleviated magically the detection problem that always obscures opportunism from the "victim." See note 61 supra \& accompanying text. If customers routinely sued for breach of duty, then the legal transaction costs would skyrocket, and the courts would be left with a potentially impossible and wholly inappropriate administrative task of assessing the fairness of every challenged deal.

${ }^{163}$ For an example of a proposal for a federal program of affirmative disclosure in products markets, see Rhoades, Reducing Consumer Ignorance: An Approach and Its Effect, 20 ANrrtrust Bulletin 309 (1975). 